\title{
International Trade and Unemployment: Theory and Cross-National Evidence*
}

Accepted: Journal of International Economics

\author{
Pushan Dutt \\ INSEAD
}

\author{
Devashish Mitra $^{\dagger}$ \\ Syracuse University
}

\author{
Priya Ranjan \\ University of California - Irvine
}

January, 2009

\begin{abstract}
We present a model of trade and search-induced unemployment, where trade results from Heckscher-Ohlin (H-O) and/or Ricardian comparative advantage. Using cross-country data on trade policy, unemployment, and various controls, and controlling for endogeneity and measurement-error problems, we find fairly strong and robust evidence for the Ricardian prediction that unemployment and trade openness are negatively related. This effect dominates the positive $\mathrm{H}-\mathrm{O}$ effect of trade openness on unemployment for capital-abundant countries, which turns negative for labor-abundant countries. Using panel data, we find an unemployment-increasing short-run impact of trade liberalization, followed by an unemployment-reducing effect leading to the new steady state.
\end{abstract}

Keywords: Trade, Search, Unemployment, Ricardian, Heckscher-Ohlin JEL Classification Codes: F11, F13, F16, J64

\footnotetext{
* We are indebted to the editor, Jonathan Eaton and two anonymous referees for extremely useful comments and suggestions. The standard disclaimer applies.

† Corresponding author: Department of Economics, The Maxwell School of Citizenship \& Public Affairs, Syracuse University, Eggers Hall, Syracuse, NY 13244, Email: dmitra@maxwell.syr.edu, Ph: (315) 443-6143, FAX: (315) 443-3717.
} 


\section{Introduction}

While unemployment is one of the big economic problems, trade economists have generally tended to abstract away from it. Most trade models are full employment models with fully flexible wages. Implicitly, this means trade economists do not believe that trade is an important factor in the determination of unemployment. There are, of course, exceptions to this rule, and there does exist a small but growing literature on the relationship between trade and unemployment. ${ }^{1}$ Outside the economics profession, there are people who believe that one of the important effects of trade is the destruction of jobs, leading to significant unemployment. Such reports are common in the various popular forms of the news media which completely ignore the creation of new jobs as a result of international trade. ${ }^{2}$ Therefore, there is a need for not only theoretical work but also rigorous empirical work investigating the effects of trade on unemployment. ${ }^{3}$

In this paper, we present a model of trade and unemployment, in which unemployment is search induced and trade arises as a result of Ricardian comparative advantage based on relative technological differences and/or Heckscher-Ohlin comparative advantage based on international differences in relative factor endowments.

Trade affects unemployment through these above sources of comparative advantage in different ways. If trade is solely driven by Ricardian comparative advantage, then trade liberalization (or tariff reduction) will result in a reduction in unemployment. However, trade driven by Heckscher-Ohlin based comparative advantage is expected to reduce unemployment only if the country in question is labor-abundant. Through this channel, trade liberalization in fact can increase unemployment in a labor-scarce economy. While this second part of the Heckscher-Ohlin prediction has the potential to be music to the ears of protectionists

\footnotetext{
${ }^{1}$ The most prominent contributors to this literature are Carl Davidson and Steve Matusz. See Davidson et al. (1999) for a representative work and Davidson and Matusz (2004) for a survey. Also see Moore and Ranjan (2005) and Mitra and Ranjan (2007) for recent contributions to this literature.

${ }^{2}$ A search of news articles in the New York Times since 1990, reveals a total of 275 articles on NAFTA as the primary subject. Out of this, 147 articles talk about job destruction in the US as a consequence of NAFTA. Also, Davidson and Matusz (2004) point out that most of the statements made in the House and the Senate during the NAFTA debate were about NAFTA's impact on jobs. They point out, that in sharp contrast, there is not a listing for unemployment in the index of the 4000 pages long Handbook of International Economics, primarily used by academic economists.

${ }^{3}$ Empirical work on trade and unemployment is virtually non-existent. An exception is some analysis of the correlation between job destruction and net exports across sectors in chapter 4 of the book by Davidson and Matusz (2004). They find a negative correlation between the two (equivalent to a positive correlation between net imports and job destruction), and perform some further regressions to look deeper into this correlation. See Davidson and Matusz (2005) for a more detailed empirical analysis. For an in-depth and interesting political-economy empirical analysis of how labor turnover in the US determines support for or against free trade and whether it is along factor lines or industry lines, see Magee, Davidson and Matusz (2002).
} 
in developed countries, our empirical work does not find much support for this prediction. We in fact find fairly strong and robust empirical support from our cross-country regressions for the Ricardian prediction that trade openness and unemployment are negatively related across all countries. It is important here to understand the intuition behind this result. Let us consider a two-sector, single-factor (labor), smallcountry Ricardian model. In this setting, trade results in an increase in the value of the marginal product of labor in one of the sectors (the export sector) due to an increase in the domestic relative price of the good produced in that sector. Since trade in this set up leads to complete specialization and the other sector (the import-competing sector), where the value of marginal product of labor would have been lower, cannot survive trade liberalization, the economywide value of marginal product of labor also goes up. There is more investment in job search and the posting of jobs and we get a reduction in unemployment.

A similar unemployment reducing effect of trade liberalization is obtained in the theoretical work of Felbermayr, Prat and Schmerer (2008), where also this effect is productivity driven. However, the increase in aggregate productivity upon trade liberalization happens through the weeding out of the least productive firms and the labor reallocation into relatively more productive firms in a model of heterogeneous firm productivity. The opposite result is obtained in Helpman and Itskhoki (2007) where there is, in addition to a differentiated-products, heterogeneous-productivity sector with labor-market frictions, a homogenous good sector with no labor-market frictions (and therefore, no unemployment). To the extent that trade leads to higher aggregate productivity in the differentiated products sector, this sector expands in size and the other sector, which has zero unemployment, shrinks. This effect leads to a rise in economywide unemployment upon liberalizing trade. A similar result is also obtained in Janiak (2007). There are other papers in the literature, such as Davidson, Martin and Matusz (1999) and Moore and Ranjan (2005) where the effect of trade on overall unemployment is ambiguous. ${ }^{4}$

It is also important to understand the intuition behind the alternative Heckscher-Ohlin prediction, even though it seems empirically not to be the dominant effect of trade on unemployment. When the two tradable goods here are produced using labor and capital at different factor intensities, before the opening of trade the relative price of the capital-intensive good is lower in a relatively capital-abundant country than in the rest of the world. Therefore, opening up to trade will imply an increase in the relative price of the capital-intensive good in this country. Thus the demand for capital relative to labor goes up. There is here a modified Stolper-Samuelson effect - the wage falls, the rental on capital rises and the unemployment rate rises. The results in this model are reversed in a country that is labor-abundant as trade increases the implicit demand for the services of labor relative to those of capital, which implies that the wage rate goes up and unemployment goes down.

\footnotetext{
${ }^{4}$ In Davidson, Martin and Matusz the results depend on intersectoral and international differences in labor-market frictions. In Moore and Ranjan, there are two kinds of labor (skilled and unskilled) and the effects of trade on the unemployment of these two kinds of workers go in opposite directions, making the impact on overall unemployment ambiguous.
} 
We also discuss comparative advantage arising out of differences in intersectoral asymmetries in search frictions and arising from the interaction of international differences in search efficiency and intersectoral differences in search intensity. Some of the predictions here on unemployment can look like the pure Heckscher-Ohlin ones. However, it is not possible to empirically investigate most of the predictions based on search friction asymmetries due to serious data limitations.

In our theory section, we also discuss the short-run impact effect of trade liberalization. This discussion is guided by a model of endogenous job destruction. Starting from a steady state in which the job creation rate equals the job destruction rate and not allowing intersectoral labor mobility, upon trade liberalization we get net job creation in the sector with a price rise (export sector) and net job destruction in the sector that experiences a price fall (import-competing sector). Job creation takes time, while job destruction can take place immediately. Therefore, the impact effect will be an increase in unemployment in the sector with the price fall and no change in unemployment on impact in the sector with the price rise (even though unemployment gradually falls there on its way to a new steady state). Thus, for the economy as a whole, starting from a steady state, unemployment rises at the point of impact.

Our empirical work in this paper uses cross-country data. We use a number of variables that capture trade policy such as unweighted average tariffs, import weighted average import duty, the overall trade restrictiveness index (OTRI), a measure that includes both formal and informal barriers to trade and the standard measure of openness measured as the ratio of trade to GDP. The dependent variable is overall national unemployment rate. We use several control variables that capture the varying labor-market institutions across countries. These capture the strength of labor unions, labor-market rigidity, the nature of labor laws etc. Other controls capture the varying macroeconomic economic environments of the different countries. These controls include variables such as output volatility, black-market premium etc. We also check robustness of results to instrumenting our trade policy variables. The reasons for instrumenting arise from the endogeneity of trade policy to unemployment as well as possible measurement errors in trade policy variables. The instruments we use include the number of years as a GATT/WTO member since the GATT was founded and a lagged variable to capture reliance on tax revenues from domestic sources. For the traditional openness measure, we use gravity-based variables and additional geographical variables as instruments. In these cross-country regressions, we are investigating steady-state theoretical predictions, and so we primarily use decade averages of data to maximize coverage.

We find fairly strong evidence for the Ricardian prediction that unemployment and trade openness are negatively related (protection and unemployment are positively related). Our results confirming this prediction are robust to the inclusion and exclusion of controls, and hold using both ordinary least squares as well as instrumental-variables approaches. We find only weak support for the alternative H-O prediction that the relation between trade and unemployment changes from negative to positive as we move from labor- 
abundant to capital-abundant countries. These results, by no means, imply the absence of Heckscher-Ohlin type effects that occur through changes in the sectoral composition of the economy. Rather, it is quite likely that such effects, when they go in the opposite direction, get dominated by Ricardian-type productivityrelated effects of trade on unemployment. This seems to us to be the most plausible interpretation of our empirical results.

We also use panel data to look at the short-run impact effect of trade liberalization. As predicted by theory that endogenizes job destruction, we find that trade liberalization leads to an immediate short-term increase in unemployment. Unemployment, however, starts to decline after a lag, and our estimates imply an overall long-run decline in unemployment.

The plan of the rest of the paper is as follows. We first present a unified model from which we derive as special cases, the Ricardian and Heckscher-Ohlin implications of trade liberalization for unemployment. We also derive predictions based on comparative advantage driven by asymmetries in search frictions. We then derive predictions regarding the impact effect of trade from a model of endogenous job destruction. Having derived empirical predictions from the theoretical model, we undertake our empirical analysis.

\section{Theory}

\subsection{Production Structure}

Consider an economy that produces a single final good and two intermediate goods. The final good is non-tradable, while the intermediate goods are tradable. The final good is denoted by $Z$ and the two intermediate goods are denoted by $X$ and $Y$. Further, denote the prices of $X$ and $Y$ in terms of the final good as $p_{x}$ and $p_{y}$, respectively. The production function for the final good is as follows:

$$
Z=\frac{A X^{1-\alpha} Y^{\alpha}}{\alpha^{\alpha}(1-\alpha)^{1-\alpha}} ; 0<\alpha<1
$$

Given the prices $p_{x}$, and $p_{y}$, of inputs, the unit cost for producing $Z$ is given as follows.

$$
c\left(p_{x}, p_{y}\right)=\frac{1}{A}\left(p_{x}\right)^{1-\alpha}\left(p_{y}\right)^{\alpha}
$$

Since $Z$ is chosen as the numeraire, $c\left(p_{x}, p_{y}\right)=1$, or

$$
\frac{1}{A}\left(p_{x}\right)^{1-\alpha}\left(p_{y}\right)^{\alpha}=1
$$

The production function for $Z$ implies the following relative demand for the two intermediate goods.

$$
\frac{X^{d}}{Y^{d}}=\frac{(1-\alpha) p_{y}}{\alpha p_{x}}
$$

Labor and capital are the two factors of production. The total number of workers in the economy is $L$, each supplying one unit of labor inelastically when employed. The amount of capital is $K$. Our description of the 
labor market corresponds to a standard Pissarides (2000) style search model embedded in a two sector set up. A producing unit in the intermediate goods production is a job-worker match. New producing pairs are created at a rate determined by a matching function of two measures of labor market participation, vacancies and unemployment. Job destruction is a response to idiosyncratic shocks to the productivity of existing job-worker matches.

Once a match is created, a firm rents capital and undertakes production. For simplicity, assume that firms can return the capital to the owner upon the destruction of a job. The production functions (in these one-worker firms) in the two intermediate goods sectors, once the matches are formed, are given by

$$
x=h_{x} k_{x}^{\phi_{x}} ; y=h_{y} k_{y}^{\phi_{y}} ; 0 \leq \phi_{i} \leq 1
$$

where $k_{i}$ is the amount of capital used in a representative single-worker firm in sector $i=x, y$, while $\phi_{i}$ is a parameter capturing the capital intensity of sector $i$ 's Cobb-Douglas production function and $h_{i}$ is the sector's technology parameter, capturing its total factor productivity. If $L_{i}$ is the total number of workers affiliated with sector- $i, u_{i}$ the unemployment rate in sector $i$, then the number of employed in sector $i$ is $\left(1-u_{i}\right) L_{i}$. The aggregate production in each sector is given by

$$
X=h_{x}\left(1-u_{x}\right) L_{x} k_{x}^{\phi_{x}} ; Y=h_{y}\left(1-u_{y}\right) L_{y} k_{y}^{\phi_{y}}
$$

and the amount of capital employed in each sector is given by

$$
K_{x}=k_{x}\left(1-u_{x}\right) L_{x} ; K_{y}=k_{y}\left(1-u_{y}\right) L_{y}
$$

Note that the composition of the economy's labor force, $L$ into $L_{x}$ and $L_{y}$ is endogenously determined in our model (as explained later). The following, therefore, represents our binding labor constraint:

$$
L_{x}+L_{y}=L
$$

The market clearing condition in the capital market implies the following.

$$
\left(1-u_{x}\right) L_{x} k_{x}+\left(1-u_{y}\right) L_{y} k_{y}=K
$$

The relative supply of the two intermediate goods is

$$
\frac{X^{S}}{Y^{S}}=\frac{h_{x}\left(1-u_{x}\right) L_{x} k_{x}^{\phi_{x}}}{h_{y}\left(1-u_{y}\right) L_{y} k_{y}^{\phi_{y}}}
$$

The total number of matches in the labor market is determined by the matching technology given as follows. Let $v_{i}$ be the vacancy rate (i.e., the number of vacancies divided by the labor force) in sector- $i$. Define $\theta_{i} \equiv \frac{v_{i}}{u_{i}}$ as a measure of market tightness, and let $m_{i}$ be a scale parameter in the matching function. Then, write the flow of matches in each sector per unit time as follows:

$$
M_{i}\left(v_{i} L_{i}, u_{i} L_{i}\right)=m_{i} v_{i}^{\gamma} u_{i}^{1-\gamma} L_{i}=m_{i} \theta_{i}^{\gamma} u_{i} L_{i} ; 0<\gamma<1
$$


where $\gamma$ is a parameter capturing the vacancy intensity of this Cobb-Douglas matching function. Then, the exit rate (from unemployment) for an unemployed searcher in sector $i$ is $\frac{M_{i}}{u_{i} L_{i}}=m_{i} \theta_{i}^{\gamma}$, and the rate at which vacant jobs are filled is $\frac{M_{i}}{v_{i} L_{i}}=m_{i} \theta_{i}^{\gamma-1}$. The former is an increasing function of market tightness, and the latter is a decreasing function of market tightness.

Assume that the matches in sector- $i$ are broken at an exogenous rate of $\lambda_{i}$ per period. $\lambda_{i}$ can be viewed as an arrival rate of a shock that leads to job destruction. Given the above description of labor market, the net flow into unemployment per period of time is

$$
\dot{u}_{i}=\lambda_{i}\left(1-u_{i}\right)-m_{i} \theta_{i}^{\gamma} u_{i}
$$

In the steady-state the rate of unemployment is constant. Therefore, the steady-state unemployment in sector- $i$ is given by

$$
u_{i}=\frac{\lambda_{i}}{\lambda_{i}+m_{i} \theta_{i}^{\gamma}}
$$

Denote the recruitment cost in sector- $i$ in terms of the final good by $\delta_{i}$, and the exogenous discount factor by $\rho$. The asset value of a vacant job, $V_{i}$, is characterized by the following Bellman equation

$$
\rho V_{i}=-\delta_{i}+m_{i} \theta_{i}^{\gamma-1}\left(J_{i}-V_{i}\right)
$$

where $J_{i}$ is the value of an occupied job.

Free entry in job creation implies $V_{i}=0$, which implies the following from (9)

$$
J_{i}=\frac{\delta_{i}}{m_{i} \theta_{i}^{\gamma-1}} ; \text { for } i=X, Y
$$

Denoting the wage of workers in sector- $i$ by $w_{i}$ in terms of the numeraire good and the rental of capital by $r$, the asset value of an occupied job, $J_{i}$, satisfies the following Bellman equation

$$
\rho J_{i}=p_{i} h_{i} k_{i}^{\phi_{i}}-r k_{i}-w_{i}-\lambda_{i} J_{i}
$$

Making use of (11) to substitute out $J_{i}$ from equation (10) we get the following equation

$$
p_{i} h_{i} k_{i}^{\phi_{i}}-r k_{i}-w_{i}=\frac{\left(\rho+\lambda_{i}\right) \delta_{i}}{m_{i} \theta_{i}^{\gamma-1}}
$$

(12) is another way to write the zero profit condition from a vacant job mentioned earlier.

The optimal choice of $k_{i}$ is determined by maximizing $J_{i}$ in equation (11) taking the wage rate $w_{i}$ and the rental $r$ as given. This leads to the following condition governing the optimal choice of $k_{i}$

$$
p_{i} h_{i} \phi_{i} k_{i}^{\phi_{i}-1}=r
$$




\subsection{Wage Determination}

On the worker side, unemployed workers in each sector receive a flow benefit of $b$ in units of the final good. This "benefit" includes the value of leisure as well as unemployment insurance payments. Let $W_{i}$ denote the present discounted value of employment in sector $i$ and $U_{i}$ the present discounted value of unemployment. The Bellman equations governing $W_{i}$ and $U_{i}$ are given by:

$$
\begin{gathered}
\rho W_{i}=w_{i}+\lambda_{i}\left(U_{i}-W_{i}\right) \\
\rho U_{i}=b+m_{i} \theta_{i}^{\gamma}\left(W_{i}-U_{i}\right)
\end{gathered}
$$

Wage is determined through a process of Nash bargaining between the worker and the entrepreneur where the value of a job for an entrepreneur is given by $J_{i}$ in (11) and the surplus of a worker from a job is $W_{i}-U_{i}$. Denoting the bargaining power of workers by $\beta$, Nash bargaining implies the following equation for wages.

$$
W_{i}-U_{i}=\frac{\beta}{1-\beta} J_{i}
$$

Note also from (15) and (16) that

$$
\rho U_{i}=b+\frac{\beta}{1-\beta} m_{i} \theta_{i}^{\gamma} J_{i}=b+\frac{\beta}{1-\beta} \delta_{i} \theta_{i}
$$

where the last equality is obtained by using (10).

By substituting out $J_{i}, W_{i}$, and $\rho U_{i}$, using (11), (14), and (17), respectively, in (16), we can derive the following expression for wage:

$$
w_{i}=(1-\beta) b+\beta\left(p_{i} h_{i} k_{i}^{\phi_{i}}-r k_{i}+\delta_{i} \theta_{i}\right)
$$

Now, a worker should be indifferent between searching in either sector. Therefore, the no arbitrage condition is given by

$$
U_{x}=U_{y}
$$

which in turn implies from (17) that in equilibrium

$$
\delta_{x} \theta_{x}=\delta_{y} \theta_{y}
$$

That is, the market tightness in each sector is proportional to the recruitment cost.

The model is solved as follows. Start with any $\frac{p_{x}}{p_{y}}$. The absolute prices $p_{x}$ and $p_{y}$ corresponding to this $\frac{p_{x}}{p_{y}}$ are obtained from (2). For this pair of prices $p_{x}$ and $p_{y}$ the following 11 variables- $w_{i}, r, \theta_{i}, u_{i}, L_{i}, k_{i}$ can be found from the equations (4), (5),(8), (12), (13), (18), (19), all derived above.

Next, we make the following assumption and discuss the implications of relaxing it later. 
Assumption 1: The search parameters are symmetric across the two sectors, i.e., $m_{x}=m_{y}, \delta_{x}=$ $\delta_{y}, \lambda_{x}=\lambda_{y}$

From the (19) we get $\theta_{x}=\theta_{y}$. From (12) and (18) we get

$$
w_{i}=b+\frac{\beta}{1-\beta}\left(\delta_{i} \theta_{i}+\frac{\left(\rho+\lambda_{i}\right) \delta_{i}}{m_{i} \theta_{i}^{\gamma-1}}\right)
$$

Therefore, under assumption 1 above we get $w_{x}=w_{y}$.

It can also be verified that for a given product price ratio, a higher $b, \beta$ or $\delta$ leads to a lower $\theta$ and consequently a higher unemployment. In the empirical exercise we will use proxies for $b$ and $\beta$ as controls.

\subsection{The Case of Ricardian Comparative Advantage}

In addition to assumption 1, we make the following assumption on factor intensities:

Assumption 2: The capital intensities are the same in both sectors, i.e., $1>\phi_{x}=\phi_{y}=\phi \geq 0$.

Under assumption 2 the two production functions differ only by a constant productivity term $h_{i}$. In this sense, the case we are analyzing is Ricardian. ${ }^{5}$

Since $w_{x}=w_{y}$, it implies from (12) and (13) that under assumption 2

$$
(1-\phi) p_{x} h_{x} k_{x}^{\phi}=(1-\phi) p_{y} h_{y} k_{y}^{\phi}
$$

Upon substituting the expression for $k_{i}$ from (13) in the above we get the result that the relative price must satisfy the following.

$$
\frac{p_{x}}{p_{y}}=\frac{h_{y}}{h_{x}}
$$

That is, under the identical factor intensity assumption, the relative price is determined by purely exogenous productivity differences between the two sectors.

\subsubsection{International Trade}

Suppose this economy is now opened up to international trade. Also, suppose this economy has a comparative advantage in $X$ and is a small open economy. Therefore, the autarky price of $X$ is less than its world price. Using the $A$ superscript to denote autarky and $W$ superscript to denote world, we have $\left(\frac{p_{x}}{p_{y}}\right)^{A}=\frac{h_{y}}{h_{x}}<\left(\frac{p_{x}}{p_{y}}\right)^{W}$. After opening up to trade the relative price of $X$ will rise to the world relative price and hence $h_{x} p_{x}>h_{y} p_{y}$. This implies from (13) that $k_{y}<k_{x}$ and hence $h_{y} p_{y} k_{y}^{\phi}<h_{x} p_{x} k_{x}^{\phi}$. Since the vacancy costs and the bargaining power of workers are the same across the two sectors, Nash bargaining implies that the same wage rate will have to be paid in the two sectors if both sectors exist. However,

\footnotetext{
${ }^{5}$ Clearly, $\phi_{x}=\phi_{y}=0$ is a special case of the model of Ricardian comparative advantage described above, and that is the case where only labor gets used in the production of the two goods and thus, capital is no longer a productive factor. Thus, this boils down to a traditional one-factor Ricardian model and all the results derived for $\phi_{x}=\phi_{y} \geq 0$ will hold.
} 
$h_{y} p_{y} k_{y}^{\phi}<w_{x}+\frac{(\rho+\lambda) \delta}{m \theta^{\gamma-1}}=h_{x} p_{x} k_{x}^{\phi}$, and hence sector $Y$ is no longer viable in the economy. Therefore, as in the standard Ricardian model, the economy will specialize in the production of $X$.

What happens to unemployment after opening to trade? An increase in $\left(\frac{p_{x}}{p_{y}}\right)$ implies from $(2)$ an increase in $p_{x}$ and a reduction in $p_{y}$. An increase in $p_{x}$ implies increased profitability of jobs in the $X$ sector at autarky $w_{x}$ and $\theta$. On the other hand, there is a reduction in the profitability of jobs in the $Y$ sector. This leads to more job creation in the $X$ sector and a reduction in job creation in the $Y$ sector. Thus the wage and market tightness are pushed up in the $X$ sector and they are pushed down in the $Y$ sector, which makes $X$ sector more attractive for workers. An increase in $p_{x}$ also increases the value of the marginal product of capital in the $X$ sector (and reduces the value of the marginal product of capital in the $Y$ sector) which leads to a movement of capital away from the $Y$ sector into $X$ sector. The consequent increased capital per worker in the $X$ sector further increases the value of a job there leading to further job creation. The process stops once all capital and labor have moved to the $X$ sector. In an online appendix (http://faculty.insead.edu/dutt/unemp) to this paper, we verify that, starting from the autarky price, as $p_{x}$ increases, $\theta$ increases, which in conjunction with (20) and (8), leads to an increase in $w$ and a decrease in $u$. Thus, movement from autarky to free trade reduces the unemployment rate and increases the wage rate.

Starting from a positive tariff on good $Y$, trade liberalization (reduction in the tariff) has a similar effect. Even though there is complete specialization in this model (in the presence of a tariff that is not totally prohibitive), unemployment responds to tariff here. A reduction in tariff leads to an increase in the domestic price of $X$ and therefore an increase in $w$ and a reduction in the unemployment rate.

Thus we have the following result:

Proposition 1 Opening up to trade or a reduction in import tariffs in a two-sector model of Ricardian comparative advantage with search-generated unemployment (and with symmetric labor-market frictions across the two sectors) leads to a decrease in unemployment and an increase in the real wage of workers.

A similar result can be derived in a Ricardian model with a continuum of goods.

\subsection{Comparative Advantage Based on Factor Proportions (Heckscher-Ohlin)}

In place of Assumption 2, we now make the following strong factor intensity assumption.

Assumption 3: $\phi_{x}>\phi_{y}>0$

We continue to make assumption 1 of identical search parameters across sectors. We can easily show that the relative supply of good $X$ is increasing in the relative price $\frac{p_{x}}{p_{y}}$. Using (12), (13), (18), and (20) we 
get

$$
\begin{aligned}
& k_{x}=\left(\frac{\phi_{y}}{\phi_{x}}\right)^{\frac{\phi_{y}}{\phi_{x}-\phi_{y}}}\left(\frac{1-\phi_{x}}{1-\phi_{y}}\right)^{\frac{\phi_{y}-1}{\phi_{x}-\phi_{y}}}\left(\frac{h_{x} p_{x}}{h_{y} p_{y}}\right)^{\frac{1}{\phi_{y}-\phi_{x}}} \\
& k_{y}=\left(\frac{\phi_{y}}{\phi_{x}}\right)^{\frac{\phi_{x}}{\phi_{x}-\phi_{y}}}\left(\frac{1-\phi_{x}}{1-\phi_{y}}\right)^{\frac{\phi_{x}-1}{\phi_{x}-\phi_{y}}}\left(\frac{h_{x} p_{x}}{h_{y} p_{y}}\right)^{\frac{1}{\phi_{y}-\phi_{x}}}
\end{aligned}
$$

Therefore, an increase in $\frac{p_{x}}{p_{y}}$ decreases both $k_{x}$ and $k_{y}$. In addition, an increase in $\frac{p_{x}}{p_{y}}$, from (2), implies an increase in $p_{x}$ and a decrease in $p_{y}$. From (13), thus we have an increase in $r$. Further, since $p_{y} h_{y} k_{y}^{\phi_{y}}-r k_{y}=$ $\left(1-\phi_{y}\right) p_{y} h_{y} k_{y}^{\phi_{y}}$ and both $p_{y}$ and $k_{y}$ decrease, $p_{y} h_{y} k_{y}^{\phi_{y}}-r k_{y}$ decreases as well. Next, note that identical wages (due to identical $\theta$ from identical $\delta$ ) in the two sectors imply

$$
p_{y} h_{y} k_{y}^{\phi_{y}}-r k_{y}=p_{x} h_{x} k_{x}^{\phi x}-r k_{x}
$$

Since the l.h.s of (24) decreases, it implies a decrease in r.h.s. as well. Now, it can be easily shown using (12) and (18) that this leads to a decrease in $w$ and $\theta$, and consequently an increase in $u$. Intuitively, when $p_{x}$ increases and $p_{y}$ decreases, in order for sector $Y$ to remain viable, the labor cost must decrease because sector $Y$ is relatively labor abundant. This is accomplished by a decrease in $w$ and $\theta$.

Since the two sectors have identical $\theta$, the sectoral unemployment rates are identical as well, therefore, the factor market clearing condition (5) can be written as

$$
\varepsilon k_{x}+(1-\varepsilon) k_{y}=\frac{K}{(1-u) L}
$$

where $\varepsilon=\frac{L_{x}}{L}$ is the share of sector $X$ in the total labor force, and $L_{x}$ is the amount of labor affiliated with sector $X$ in steady state. With this notation, we can write the relative supply of the two intermediate goods $X$ and $Y$ as

$$
\frac{X^{s}}{Y^{s}}=\frac{\varepsilon h_{x} k_{x}^{\phi_{x}}}{(1-\varepsilon) h_{y} k_{y}^{\phi_{y}}}
$$

In the online appendix (http://faculty.insead.edu/dutt/unemp), we have proved that $\frac{X^{s}}{Y^{s}}$ is increasing in $p \equiv \frac{p_{x}}{p_{y}}$. From (3) we know that $\frac{X^{d}}{Y^{d}}$ is decreasing in $p$. Therefore, the autarky equilibrium is obtained by the intersection of the relative demand and the relative supply curves.

What happens when $\frac{K}{L}$ increases? We have shown above that $u, k_{x}$ and $k_{y}$ are fully determined by $p$. Thus, holding $p$ constant implies setting $d k_{x}=d k_{y}=d u=0$. Holding $p$ constant, from equation (25) we have

$$
\left(k_{x}-k_{y}\right) d \varepsilon=\frac{1}{(1-u)} d\left(\frac{K}{L}\right)
$$

Holding the relative price $p$ constant, the only impact of an increase in $\frac{K}{L}$ is to increase $\varepsilon$, which in turn implies a rightward shift in the relative supply curve. Therefore, the equilibrium relative price $p$ is lower the larger the $\frac{K}{L}$. Therefore, $\frac{K}{L}$ becomes a source of comparative advantage as in the standard Heckscher-Ohlin model. 


\subsubsection{Impact of Trade}

Assuming that our economy is capital-abundant relative to rest of the world, before the opening of trade in the intermediate goods, the comparative statics discussed earlier implies that the relative price of the capital intensive intermediate good $X$ is lower in our economy. Therefore, opening up to trade in the intermediate goods will imply an increase in the relative price of $X$. So, the impact of trade in intermediate goods is captured by an increase in the relative price $\frac{p_{x}}{p_{y}}$. This implies an increase in $p_{x}$ and a decrease in $p_{y}$. As discussed earlier, this leads to the following changes: $d w<0, d r>0$, and $d \theta<0, d u>0$. The opposite happens to a country having a comparative advantage in the labor intensive good. Intuitively, even though job creation becomes more attractive in the $X$ sector upon impact, the consequent increase in the rental of capital reduces the value of a job in both sectors leading to increased unemployment and lower wages in a capital abundant country. The results are summarized in proposition 2 below.

Proposition 2 The impact of international trade (or an import tariff reduction) on a capital abundant country (when search parameters across sectors are the same but factor intensity parameters different) is a decrease in the wage rate and an increase in the rate of unemployment of labor, while in the case of a labor-abundant country the wage rate goes up and unemployment goes down as a result of trade liberalization.

Why do we get different results in the Ricardian and Heckscher-Ohlin cases? Let us first look at the Ricardian case (where both sectors have the same factor intensity or alternatively where there is only a single factor). Opening to trade here destroys the viability of the sector in which the country has a comparative disadvantage. In addition, the price of the other good (the one produced in the comparative-advantage sector) goes up. Hence there is an increase in the value of a job and consequently, a reduction in steady-state unemployment. On the other hand, in the two-factor Heckscher-Ohlin world (which is a world where the two sectors have different factor intensities), the reaction to opening to trade is somewhat more complex. In a capital-abundant country, there is an expansion of the capital-intensive export (comparative-advantage) sector accompanied by a shrinking of the labor-intensive import-competing (comparative-disadvantage) sector. This leads to increased economywide demand for capital relative to labor. The consequent increase in the rental price of capital has a negative effect on the value of a job in both sectors. The net effect is increased unemployment and lower wages in a capital abundant country. The reverse is the case in a labor-abundant country.

To sum up, under assumption 1 on identical search parameters in the two sectors we derive unambiguous implications of trade for unemployment in the two classic models of trade: the Ricardian model and the Heckscher-Ohlin model. Since in our empirical exercise we are unable to control for search parameters, this was the appropriate theoretical framework to present. However, the unambiguous theoretical predictions as well as the strict separation between Ricardian and Heckscher-Ohlin determinants of comparative advantage 
will not hold if search parameters differ across sectors and countries ${ }^{6}$. Davidson, Martin, and Matusz (1999) provide a rich model to study the impact of trade on unemployment in several different scenarios depending on whether search parameters differ across sectors and/or countries.

\subsection{The Short-Run Impact Effect of Trade Policy}

So far our theoretical exercise has focused on the steady state effects of trade on unemployment. To analyze the instantaneous impact effect of a change in trade policy assume no intersectoral mobility of labor and endogenize job destruction along the lines of Pissarides (Chapter 2). A firm-job pair starts at full productivity at the point of creation. At each subsequent point in time, a firm-specific (job-specific) productivity shock is received by each firm at a Poisson arrival rate. The threshold productivity level for a firm's survival is determined by profits corresponding to the productivity level and is the one for which the firm just breaks even. Any shock that lowers the productivity level below this leads to the destruction of the firm or job. With a change in trade policy (increase or reduction in import protection), the domestic relative price of one of the two sectors goes up, while that of the other sector goes down. In the sector where the price goes up, the threshold productivity for survival falls, as a result of which the job destruction rate falls, and market tightness and job creation rate rise. In the other sector where the price goes down, the threshold productivity rises as a result of which the job destruction rate rises and the job creation rate falls. Starting from a steady state in which the job creation rate equals the job destruction rate, upon a change in trade policy, we get net job creation in the sector with a price rise and net job destruction in the sector that experiences a price fall. Job creation takes time, while job destruction can take place immediately.

\footnotetext{
${ }^{6}$ For a detailed discussion of introducing asymmetries in the various labor market and search parameters, we refer the interested reader to our online appendix (http://faculty.insead.edu/dutt/unemp). For example, in our baseline Ricardian model $\left(\phi_{x}=\phi_{y}>0\right)$, we know that the capital intensity is the same in the two sectors if they both face the same factor costs. However, if under such conditions, we introduce search cost asymmetries across sectors, we will get different costs per unit of labor in the two sectors. Wage plus search cost per worker will be higher in the sector with the higher vacancy cost, and so the relative factor costs (inclusive of search costs) faced will be different in the two sectors. Thus, ex post the capital intensities in the two sectors will be different. Ex post, the sector with the higher search cost will be more capital intensive. If the sectoral search costs are the same across countries (within a sector), a capital abundant country will have a comparative advantage in the sector with the higher vacancy costs. When such a country opens up to trade, the domestic price of good produced in the higher vacancy cost (ex post capital-intensive) sector goes up and that in the other sector goes down. Thus, due to the expansion of the capital-intensive sector (and a contraction of the labor-intensive sector) we should expect to have a reduction in the economy's overall demand for labor and therefore, a reduction in labor market tightness and an increase in unemployment in each of the two sectors. Also, as mentioned above, the share of the ex post capital intensive (the higher unemployment) sector goes up. Thus, we should expect an increase in unemployment. By symmetric logic, unemployment in a labor-abundant country should go down when it opens up to trade. Thus we have a composition effect that goes very much in the same direction as the Heckscher-Ohlin prediction in proposition 2 even though the two sectors had identical factor intensities ex ante.
} 
Therefore, the impact effect will be an increase in unemployment in the sector with the price fall (and in the overall economy) and no change in unemployment on impact in the sector with the price rise (even though unemployment gradually falls there on its way to a new steady state), irrespective of whether the capital intensities are the same or different in the two sectors.

\subsection{The Role of Labor Force Participation}

In our analysis, we have so far abstracted from labor force participation. As is discussed in the online appendix (http://faculty.insead.edu/dutt/unemp), this is not a problem if the matching function exhibits constant returns to scale (which has been found to be empirically valid) as is assumed in the theoretical model. Constant returns in matching makes unemployment independent of the size of the labor force. Even if the matching function exhibits non constant returns to scale, not controlling for labor force participation (as long as one is controlling for working age population) is not a problem. The labor force participation rate is then a function of the working age population. Plugging this function into a function determining unemployment gives us a reduced form function for the unemployment rate that has working age population as an argument but not labor force participation rate. Only if we really want to know the effect of trade policy on the unemployment rate specifically for given participation rates, do we control for and instrument the labor force participation rate.

\section{Data Description}

To examine the relationship between trade protection and unemployment we collected data on multiple trade policy measures, unemployment rates and a variety of controls over the period 1990-2000. Details on the variables used, along with additional results are available in an online appendix (http://faculty.insead.edu/dutt/unemp). We use the 1990s' average for our cross-sectional analysis and the time series for each country for the period 1985-2004 for our panel analysis.

\subsection{Unemployment rate}

Our dependent variable is the unemployment rate (as percentage of the labor force) from the International Finance Statistics. For our cross-sectional analysis, this variable is averaged over the decade of the 1990s to smooth out any business cycle fluctuations. We have data on 92 countries and the variable ranges from a low of $0.9 \%$ for Azerbaijan to a high of $55.6 \%$ for Ethiopia. ${ }^{7}$

\footnotetext{
${ }^{7}$ In our sample, Ethiopia drops out due to missing data on labor market institutions.
} 


\subsection{Trade Policies}

Countries resort to a variety of policy instruments in order to protect trade. These include: tariffs, quotas, non-automatic licensing, antidumping duties, countervailing duties, tariff-rate quotas, export taxes, etc. Finding a single measure of trade protection that summarizes such a multiplicity of instruments is a task economists have long struggled with. Since it is impossible to capture and summarize the wide variety of trade policy instruments used, we use the following policy measures in addition to an outcome measure, $\left(\frac{X+M}{G D P}\right) .8$ Our first direct measure is the unweighted average external tariff data recently made available by the World Bank. A second measure is total import duties collected as a percentage of total imports from the World Development Indicators (also averaged for the 1990s). ${ }^{9,10}$ Given that tariffs are only one of many direct measures of trade protection, Kee, Nicita and Olarreaga (2006) have attempted to combine the myriad trade policy instruments into an Overall Trade Restrictiveness Index (OTRI). It is the equivalent uniform tariff that would keep imports of a country at their observed levels, and it also takes into account the ad-valorem equivalent of non-tariff barriers. The construction methodology follows that of Anderson and Neary (1994). Finally, due to the presence and importance of informal trade barriers in the determination of trade patterns and volumes (See Anderson and Marcouiller, 2002), we use a measure from the Economic Freedom of the World Project. This measure is based on a survey question from the Global Competitiveness Report that asks respondents to rate hidden import barriers. Countries receive a rating from 0-10 with higher numbers indicating lower barriers. We combine this rating with a similar rating on formal trade barriers (tariffs and trade tax revenues) using a simple average. Thus our modified GCR measure is a combination of both informal/hidden and formal barriers. In addition, it is recoded as 10 minus original rating to make our modified GCR measure increasing in the size of the trade barriers. This variable is available for a single year in the 1990s. ${ }^{11}$

\footnotetext{
$8\left(\frac{X+M}{G D P}\right)$, while capturing the effects of many different trade related policies, can also capture the effects of policies and structural characteristics, unrelated to trade policy. These could include differences in tastes, macroeconomic shocks and policies, geographic attributes, and other factors such as rainfall.

${ }^{9}$ Note the import duty measure is a weighted average of import duties on each good where the weights are the share of imports of that good in total imports.

${ }^{10}$ While neither the average tariff measure nor the import duty measure is perfect due to the numerous problems arising from their highly aggregate nature, Rodriguez and Rodrik (2000) argue that these are the most direct measures of trade restrictions, with little evidence for the existence of serious biases, and that they do a relatively decent job in ranking countries according to the restrictiveness of their trade regimes.

${ }^{11}$ We also examined quota coverage ratio as a measure of protection. However, this variable is available for only 28 countries for a single year in the 1990s. Results with this measure are available in the online appendix.
} 


\subsection{Controls}

Botero et al (2004) argue that every country in the world has established a complex system of laws and institutions intended to protect the interests of workers and to help assure a minimum standard of living for its population. These include employment laws that govern the individual employment contract, and collective or industrial relations laws that regulate the bargaining, adoption, and enforcement of collective agreements, the organization of trade unions, and the industrial action by workers and employers. We use their index of employment laws that captures the rigidity of alternative employment contracts, cost of increasing hours worked, cost of firing workers, and difficulty of dismissal procedures. The index measures both the legal and effective protection available to workers. Our second control is an index of labor union power again from Botero et al (2004). This variable measures protection afforded to and the power of labor unions. Controlling for labor union power and employment laws is critical since this could lead to an omitted variable bias. Countries with strong union power are likely to exhibit both higher levels of trade protection and higher rates of unemployment. ${ }^{12}$ Both measures are available for a single year (1997). A third institutional control is the civil rights index from Freedom House. Measured on a scale of 1 to 7, with higher numbers signifying greater restrictions on civil liberties, this variable captures freedom of expression, the right to organize, the rule of law and personal autonomy.

To control for the effect of recessions and expansions, booms and busts, financial crises, output collapse in former communist Eastern European states etc., we include a measure of output volatility. We follow Ramey and Ramey (1995) and measure output volatility as the standard deviation of the annual growth rate of GDP per capita for each of the countries in our sample over the period 1990-2000. We also included the Black Market Premium on the exchange rate to capture macroeconomic distortions. We control for the size of the economy using the working-age population in the ages $15-64^{13}$ and real GDP from World Development Indicators. The two controls together would also effectively control for GDP per capita, which is a measure of the level of development . Finally, as a robustness check we add measures of labor market participation - both the total participation rate (percentage of total population between the ages 15-64 who are economically active) and female labor market participation rate (economically active females as a percentage of the female population of ages 15-64). Both variables are from the World Development Indicators.

Tables 1 provides the summary statistics of all our variables.

\footnotetext{
${ }^{12}$ Within a Heckscher-Ohlin framework, strong union power is likely to result in higher protection and higher unemployment for capital-abundant countries only. In labor-abundant countries, a stronger lobbying presence by workers should result in lower protection. We evaluated this by including an interaction between labor union power and $\mathrm{K} / \mathrm{L}$ in $\mathrm{H}-\mathrm{O}$ model. The interaction variable however, proved to be insignificant. We also used data on trade union membership as a percentage of labor force from Rama and Artecona (2002). This variable was not significant in any of the specifications.

${ }^{13}$ Our measure is the working-age population in a country between the ages $15-64$.
} 


\section{Trade Protection and Unemployment: Results}

\subsection{Ricardian Specification}

Proposition 1 states that within a model of Ricardian comparative advantage a higher tariff should lead to higher levels of unemployment. We evaluate this proposition by regressing the unemployment rate on each of our 6 measures of trade policy. Our objective is to examine whether more protectionist countries experience higher rates of unemployment, and whether this relationship is robust to controlling for labor laws, macroeconomic distortions and country size, and to endogeneity concerns, and that the relationship holds both across countries and within countries over time.

Figure 1 (presented right above Table 2) shows the correlation between unemployment rate and the unweighted tariff measure. ${ }^{14}$ There is a clear positive relationship between unemployment and tariffs. The unconditional raw correlation is positive and significant at the $1 \%$ level of significance.

\subsubsection{OLS Estimates}

Tables 2 and 3 check the robustness of this relationship to alternate measures of protection and to the inclusion of controls. Table 2 shows that almost all our measures of trade protection, are positively and significantly associated with higher rates of unemployment. ${ }^{15}$ All models as a whole are significant and our variables account for $4-24 \%$ of the cross-country variation in unemployment rates. Table 3 shows that this relationship is robust to controlling for country size, for labor union power, for employment laws, for macroeconomic distortions and fluctuations, and civil liberties. Here our variables account for $20-49 \%$ of the cross-country variation in unemployment rates. In terms of the controls, we find evidence that countries where labor unions have greater power also exhibit higher rates of unemployment. This is consistent with the outcome of our comparative static exercise with respect to $b$ and $\beta$ alluded to in the theory section. ${ }^{16}$

The numbers in table 3 imply that a $1 \%$ increase in the average tariff rate increases the unemployment rate by about $0.35 \%$. Across protection measures, the unweighted tariff rate has the strongest effect $-\mathrm{a}$ one standard deviation increase in leads to a $2.4 \%$ increase in the unemployment rate. The corresponding numbers for import duties, OTRI, GCR, and openness measures are $2.3 \%, 1.7 \%, 2.1 \%$ and $-1.2 \%$, respectively.

\footnotetext{
${ }^{14}$ Similar graphs using alternate protection measures are available in the online appendix.

${ }^{15}$ Note that $\left(\frac{X+M}{G D P}\right)$ is a measure of openness so we expect a negative sign on this variable.

${ }^{16}$ If we use the quota measure, it has the right sign, but is not significant. Partly this is due to the limited data on this measure and partly because the variable is subject to measurement error. The coverage ratio only suggests that barriers to trade exist, but cannot measure their effect (see Harrigan, 1993.) In fact, once we instrument quotas, we obtain a positive and significant coefficient, suggesting attenuation bias.
} 


\subsubsection{More Controls and Instrumental Variable Estimates}

There are two potential problems with the results reported in table 3: omitted variables and endogeneity of trade policies. It is plausible that an omitted variable may affect both unemployment and trade policies. For instance, countries that follow good macroeconomic policies may also be less protectionist. While we have two controls for macroeconomic distortions, output volatility and the black market premium on the exchange rate, the omitted variable critique can still be made. Second, countries that exhibit higher unemployment may face populist pressures (domestically) to raise trade barriers (reverse causality). Indeed, this version of the reverse causality argument does generate a positive (conditional) correlation between unemployment and protection.

First, we experimented with a host of other macroeconomic policies as controls. Since monetary policy is frequently used as a tool to manage the trade-offs between inflation and unemployment, we added controls for nominal interest rate, and inflation rates. We also controlled for deterioration in the terms of trade (between the decade of the 80s and 90s), and used a measure of domestic distortions from Alesina and Perotti (1996). Our results survive the use of these additional regressors. For instance, with tariffs, we obtain

$$
\begin{aligned}
{\text { unemployment } \text { rate }_{i}}=\underset{(0.146)}{0.348^{* * *} \text { tariff }_{i}+\text { controls }} \\
R^{2}=0.34, N=46
\end{aligned}
$$

where $* * *$ indicates significance at the $1 \%$ level. Other trade policy measures yield results similar to those in table $3{ }^{17}$

Next, we address endogeneity concerns by using instrumental variables. ${ }^{18}$ Incidentally, instrumental variables will help us also deal with measurement error problems, which might be present in many of the protectionist measures. The presence of measurement error creates an attenuation bias, i.e., it works against finding a significant relationship between protectionism and unemployment. If the instruments help us deal with the measurement error we should see an increase in the absolute value of the coefficient. If, on the other hand, endogeneity has an important impact on our OLS estimates, then we should see a decrease in the absolute value of the coefficient on trade policy.

Finding good instruments for trade policy is not a simple task. The instruments for trade policies we propose are the number of years that a country has remained outside of the GATT/WTO since its inception

\footnotetext{
${ }^{17}$ Please see the online appendix.

${ }^{18} \mathrm{~A}$ second way to deal with reverse causality is to use lagged values of the trade protection measures. When we regress unemployment in the 1990s on trade policies in the 1980s all the results on the unweighted tariff, import duties and $\left(\frac{X+M}{G D P}\right)$ are confirmed. While the coefficients are positive and significant for the protection measures (unweighted tariff and import duties) and negative and significant for the openness measure, $\left(\frac{X+M}{G D P}\right)$, the magnitude of the effect declines, as compared to those in table 3.
} 
in 1948, and the proportion of tax revenues that each country obtained from taxes on domestic activities in the 1980s. Rose (2004) finds that nearly all countries liberalized after acceding to GATT, but not immediately. The average lag between GATT accession and liberalization of the trade regime is almost a decade. So the longer a country stays outside the GATT the larger will be its degree of protectionism. The rationale for the other instrument is as follows: Rodrik (1995) argues that developed countries have advanced tax structures and are less likely to rely on trade taxes as a source of revenue. The high administrative cost of raising revenue from domestic taxes is an important reason for the use of tariffs in the early stages of development (Limão and Panagariya, 2007). To capture this revenue motive for protection, we therefore include the share of tax revenues from domestic sources in overall tax revenues for the decade of the 80s (lagged value of dependence on domestic tax revenues). ${ }^{19}$

For the outcome based measure of trade policy $\left(\frac{X+M}{G D P}\right)$, we use a distinct set of instruments. The instruments we use are those suggested by Frankel and Romer (1999) and Rose (2004). Frankel and Romer regress bilateral trade flows (as a share of a country's GDP) on measures of country mass, distance between the trade partners, and a few other geographical variables, and then construct a predicted aggregate trade share for each country on the basis of the coefficients estimated. This constructed trade share is then used as an instrument for actual trade shares. Rose (2004) calculates a remoteness index as a weighted average of a country's trading partners' GDP where the weights are distance to the trading partners. This is a multilateral analogue to geographic distance and affects trade volumes. Our first stage regressions support these conjectures across all measures and yield partial $R^{2}$ s between $18 \%$ and $57 \%$ (see second-from-last row of table 4).

Table 4 shows the IV estimates. The coefficient on all protectionist measures, apart from OTRI, remains positive and significant, while that on $\left(\frac{X+M}{G D P}\right)$ remains negative and significant. However, the number of observations for OTRI is small, so that inferences based on this measure are less likely to be valid. For a majority of the measures of trade policies, we observe only a marginal increase in the absolute value of the estimates (when we restrict our OLS estimates to the same set of countries as those in table 4.) In fact across measures of trade policy, the OLS estimates from table 3 are within the $95 \%$ confidence interval of IV coefficient estimates in table 4.

Next, we provide purely economic arguments as to why the two instruments we use are good instruments. To be valid instruments, neither should be correlated with unemployment directly in addition to being

\footnotetext{
${ }^{19}$ Two other instruments we experimented with are a developing country dummy and a variable from The World Values Survey which reports the proportion of respondents in each country who feel that imports should be limited. If governments respond to populist pressures this should also be a valid instrument for trade policies. The developing country dummy helps capture the fact that developing country members of the GATT often get concessions with respect to showing reciprocity to trade reforms by other member countries. The coefficient on trade policies remain positive and significant if we use either or both these measures as additional instruments. All first stage regressions are available from the authors on request.
} 
related to it through our right-hand side variables, i.e., the instrumental variables should not be correlated with the error terms of our regressions. First, the number of years outside the GATT/WTO will affect unemployment only through the tariff level, since negotiations on trade policies are the primary function of GATT/WTO. ${ }^{20}$ Also this variable is not expected to be endogenous to unemployment. Second, the lagged value of the dependence of a country on domestic sources of revenues should not have any additional relationship with unemployment above and beyond the one through tariffs and beyond what is captured by a country's income level. Finally, the gravity and additional geographical variables used to instrument openness are completely exogenous to our model and should not be correlated with unemployment above and beyond their correlation through our right-hand side variables. We also provide some econometric justifications for the validity of our instruments. Hansen-Sargan tests (the p-value is reported on the last row of table 4) fail to reject the null hypothesis of overidentifying restrictions confirming the validity of our instruments. The only exception is the OTRI measure where again the small sample size comes in the way of making valid inferences. Moreover, for all estimates, apart from OTRI, the conditional likelihood ratio statistic of Moreira, the Anderson-Rubin test, and the Stock-Wright $S$-statistic reject the null hypothesis that the coefficient of protection in the structural equation (unemployment as a function of protection and controls) equals zero. These tests are robust to the presence of weak instruments (Stock, Wright and Yogo, 2002.)

\subsubsection{Controls for labor force participation}

Based on the arguments in the subsection on the role of labor force participation in the theory section, we try to control for labor force participation. If labor force participation is endogenized, it can be intuitively seen that an increase in trade protection within the context of a Ricardian model should reduce labor market participation rate, i.e., trade liberalization increase labor force participation. When we regress labor market participation on either unweighted tariffs or import duties and include the same set of controls as in table 3, we obtain the following:

$$
\begin{aligned}
{\text { labor participation } \text { rate }_{i}} & =\underset{(0.125)}{-0.496^{* * *}} \text { tarif }_{i}+\text { controls } \\
R^{2} & =0.39, N=71 \\
\text { labor participation rate } & =\underset{(0.210)}{-0.506^{* * *}} \text { mduty }_{i}+\text { controls } \\
R^{2} & =0.32, N=67
\end{aligned}
$$

where ${ }^{* * *}$ indicates significance at the $1 \%$ level. We obtain similar results with all the other protection measures as well.

\footnotetext{
${ }^{20}$ It may be argued that countries with good macroeconomic policies are also likely to be members of the GATT/WTO. However, membership in the GATT/WTO has never been conditional on macro policies or on the level of unemployment.
} 
As a further robustness check, table 5 adds two additional controls to the regressions of trade protection on unemployment - one for labor market participation, and a second for female labor market participation. Table 5 presents estimates with two direct measures of trade protection - tariffs (columns 1-3) and import duties (columns 4-6). Columns 1 and 4 show OLS estimates while the rest present IV estimates. Columns 2 and 5 instrument only trade policy while columns 3 and 6 also instrument the labor participation variable. ${ }^{21}$ We use the crude death rate and HIV prevalence in the population aged 15-49, as additional instruments in columns 3 and $6 .{ }^{22}$ Across measures of trade policy, and for both estimation techniques, we find that countries who are more protectionist exhibit higher levels of unemployment. In fact, comparing the OLS and IV coefficient estimates in table 5 to the ones in tables 3 and 4 , we see that the magnitude of the coefficients are quite similar. Total labor participation rate does not significantly impact the unemployment rate in columns 1-3, where unweighted tariffs is the trade protection measure. For import duties, labor market participation becomes insignificant in column 6, when we control for the potential endogeneity in this measure. Finally, across all specifications, female labor market participation does not affect the unemployment rate. ${ }^{23}$

\subsection{Heckscher-Ohlin specification}

The Heckscher-Ohlin prediction, summarized in proposition 2, is that an increase in trade restrictions will raise unemployment in labor abundant countries and reduce them in capital-abundant countries. As a first pass, we classified each country as capital or labor abundant according to whether its capital-labor ratio in 1990 was above or below the median capital-labor ratio. Next, we regressed unemployment on the trade protection measures separately for the capital-abundant sample and for the labor-abundant sample. For both samples, and for each of the direct measures of trade restrictions, we obtain a positive coefficient on trade protection. However, subdividing the sample on the basis of the median is somewhat ad hoc. A priori, we do not know the critical level of $(K / L)$ where the relationship between trade restrictions and unemployment changes sign. The following specification takes care of this problem by allowing the data to tell us the exact location of this turning point:

\footnotetext{
${ }^{21}$ In a recent paper, Lee and Wolpin (2006), who structurally estimate a two-sector labor-market equilibrium argue for the inclusion of female labor participation, in such analyses. They point out, however, that the variation that is specific to the participation rate of females is a function of fertility rates and the effect of children on female home time, which can be considered fairly exogenous to our model (as well as to the Lee-Wolpin model).

${ }^{22}$ Data are from the World Development Indicators. Both variables depend overwhelmingly on the disease burden in a particular country and are completely exogenous.

${ }^{23}$ Results with the GCR measure and for $\left(\frac{X+M}{G D P}\right)$ are also robust to inclusion of the participation variables. The OTRI measure fails to be significant. See online appendix.
} 


$$
\text { Unemployment }_{i}=\alpha_{0}+\alpha_{1} T R_{i}+\alpha_{2} T R_{i} \times(K / L)_{i}+\alpha_{3}(K / L)_{i}+\mathbf{X}_{i} \boldsymbol{\beta}+\epsilon_{i}
$$

where $T R_{i}$ is the extent of trade restrictions in country $i$, Unemployment $t_{i}$ is the measure of unemployment, $(K / L)_{i}$ is the capital-labor ratio for the year 1990 and $\mathbf{X}_{i}$ is a row vector of control variables. Taking the partial derivative of Unempolyment ${ }_{i}$ with respect to $T R_{i}$, we have $\frac{\partial U \text { nempolyment }}{\partial(T R)_{i}}=\alpha_{1}+\alpha_{2}(K / L)_{i}$. The prediction of the Proposition 2 is that $\alpha_{1}>0$ and $\alpha_{2}<0$ such that $\alpha_{1}+\alpha_{2}(K / L)_{i} \gtrless 0$ as $(K / L)_{i} \lessgtr(K / L)^{*}$ where $(K / L)^{*}=-\alpha_{1} / \alpha_{2}$ is the turning point capital-labor ratio determined endogenously from the data, given our estimating equation. Another requirement for the prediction to hold is that $(K / L)^{*}$ should lie within the range of values of $(K / L)$ in the dataset, i.e., $(K / L)^{M I N}<(K / L)^{*}<(K / L)^{M A X}$.

Table 6 presents the estimates with this specification. The last two rows count the number of countries that are below (above) the critical capital labor ratio and have a positive (negative) relation between trade restrictions and unemployment. As table 6 shows, apart from the import duty measure, we have very little support for the Heckscher-Ohlin proposition. For the tariff measure $\alpha_{2}$ is positive rather than negative. For GCR, $\alpha_{1}>0$ and significant, but $\alpha_{2}$ is not significant, which indicates a positive relationship between trade barriers and unemployment. For OTRI, while the signs are correct, neither $\alpha_{1}$ nor $\alpha_{2}$ is significant. For $\left(\frac{X+M}{G D P}\right)$ the coefficients are insignificant and have the wrong sign. Even if we ignore the insignificance of the coefficients, our estimates indicate that there is not a single country with a negative relationship between trade restrictions and unemployment for the unweighted tariffs and GCR measures. For OTRI, only 7 countries exhibit such a negative relationship. Finally, for the $\left(\frac{X+M}{G D P}\right)$ measure, 41 out of 48 countries exhibit a negative relation between trade volumes and unemployment.

Import duty is the only measure for which we observe some support for the Heckscher-Ohlin proposition. Both $\alpha_{1}$ and $\alpha_{2}$ are significant and 16 out of the 47 countries exhibit a negative relationship between trade protection and unemployment. ${ }^{24}$ However, even here the Heckscher-Ohlin prediction is not very robust. When we instrument the trade protection measures (not shown), we fail to find support for the HeckscherOhlin prediction, across all measures of protection, including import duty. Similarly, once we include labor-market participation variables, $\alpha_{1}$ and $\alpha_{2}$ are insignificant across measures for trade protection (even for import duties). This is true regardless of whether or not we instrument the trade policy and labor market participation variables. These results, by no means, imply the absence of Heckscher-Ohlin type composition effects. Rather we believe that such effects get dominated by Ricardian-type productivity-related effects of trade. This interpretation of our empirical results seems most plausible to us.

\footnotetext{
${ }^{24}$ For import duty, the estimated critical capital-labor ratio equals 10.95 (in log terms) and 16 countries, whose capital-labor ratios exceed this critical value, exhibit such a negative relationship.
} 


\section{Estimation with Panel Data}

Our next objective is to examine how shifts in the degree of protection within a country affect the unemployment rate. This task is non-trivial given that unemployment rates are subject to business cycle fluctuations, longitudinal data on protection measures are sparse and trade policies tend to be very stable over time. Nevertheless, we attempt to provide at least a partial view of the robustness of our results using within-country variation. The use of yearly panel data also allows us to examine the differences between the short-run and long-run effects of trade liberalization on unemployment.

For our panel results, we examine how unemployment responds in both the short and long run to a permanent trade liberalization episode. The data on trade liberalization episode are from Wacziarg and Welch (2008) who use a variety of primary and secondary data to provide liberalization dates for 110 countries. This data extends the original Sachs-Warner data on liberalization dates for the decade of the 1990s, with liberalization dates ranging from 1950 to $2001 .{ }^{25}$ Only permanent trade liberalization episodes were considered. We operationalize our trade liberalization episode variable by coding a dummy that takes the value one in the years following a permanent trade liberalization. Otherwise it takes the value 0 . As before, we include controls for GDP, working-age population, civil liberties and the two labor participation variables. ${ }^{26}$ The data span 1985-2004 with summary statistics shown in table 1.

Our specification includes, a) the lagged unemployment rate as a regressor (lagged by one year); and b) contemporaneous and lagged values of the liberalization dummy (lagged by 1-4 years). We estimate the following dynamic specification:

$$
u_{i t}=a_{1} u_{i t-1}+b_{0} L_{i t}+b_{1} L_{i t-1}+\ldots+b_{4} L_{i t-4}+\mathbf{X}_{i t} \mathbf{B}+\left(\eta_{i}+v_{i t}\right) ; i=1,2, \ldots N ; t=2,4, \ldots T
$$

where $u_{i t}$ is the unemployment rate in country $i$ at time $t, u_{i t-1}$ is the lagged unemployment rate, $L_{i t-k}$ is liberalization dummy in country $i$ at time $(t-k)$; $\mathbf{X}_{i t}$ is the vector of control variables; $\eta_{i}$ is a time invariant country-specific effect possibly correlated with the explanatory variables and $v_{i t}$ is an error term. ${ }^{27}$

Column (1) of table 7 presents the pooled OLS estimates of equation (28). Column (2) presents fixedeffects estimates which eliminates the country-specific effect $\eta_{i}$ by demeaning the variables. However, the

\footnotetext{
${ }^{25}$ The trade liberalization dates are obtained from a comprehensive survey of country case studies of liberalization. As such they are not related to the Sachs-Warner dummy variable for openness, where the openness dummy is based on secondary data on tariffs, non-tariff barriers, the black market premium on the exchange rate, state monopoly of exports, and a socialist economic system. In a separate paper, Wacziarg and Wallack (2004) show that these liberalization dates are good indicators of the timing of major trade policy changes and are associated with sustained increases in both imports and exports.

${ }^{26}$ The labor market institution variables and the black market premium are available for only a single year. Output volatility by construction is cross-sectional since we calculate the volatility of output over time for each country.

${ }^{27}$ Measurement error in unemployment may be a concern with the presence of the lagged dependent variables on the right hand side. However, if this error is driven by country-specific specific characteristics and varies little over time, it will be subsumed within the country specific effect $\eta_{i}$.
} 
within-estimates are likely to be inconsistent as well, since the transformed lagged dependent variable is correlated with the transformed error term. ${ }^{28}$ Therefore, we employ a generalized method of moments (GMM) procedure from Arellano and Bond (1991) to generate consistent estimates of the parameters of interest. Estimation proceeds by first differencing the equation (28) - this eliminates the country-specific effects $\eta_{i}$ from the model - and instrumenting the lagged dependent variable by appropriately lagged levels of the unemployment rate. We examine two sub-cases: In the first (column 3 of table 7), the liberalization episode is assumed to be predetermined so that $E\left[L_{i t} v_{i s}\right]=0$ for all $s \geq t$ and $E\left[L_{i t} v_{i s}\right] \neq 0$ for all $s<t$. In the second (column 4 of table 7), the liberalization episode is assumed to be endogenous, $E\left[L_{i t} v_{i s}\right]=0$ for all $s>t$ and $E\left[L_{i t} v_{i s}\right] \neq 0$ for all $s \leq t$. In both cases, appropriately lagged values of $L_{i t}$, are available as instruments. Finally, column 5 adds the labor market participation variables to column 4 . For the other explanatory variables, we adopt the weaker assumption that $G D P_{i t}$ and labor participation variables are predetermined, and that the working-age population and civil rights are exogenous.

Across specifications, we observe a very interesting pattern in the responsiveness of unemployment to trade liberalization. The positive and significant coefficient on contemporaneous liberalization dummy indicates a rise in unemployment in the year of liberalization. However, the negative and significant coefficients on the same variable at lags 1 and 2 show that unemployment over a longer time lag experiences a reduction due to trade liberalization. The dislocations caused by trade liberalization lead to an immediate short-term spike in unemployment rates - a magnitude of increase is about $0.6 \%$ from column 3 . Over a longer time horizon of 2-3 years, employment recovers, and the rise in unemployment reverses. The liberalization episode eventually leads to a long-run decline of $3.5 \%$ according to the coefficient estimates in column 3 . In column 4, where we treat the liberalization dummy as endogenous, the estimates imply a $2.5 \%$ decline in the unemployment rate in the long-run following a permanent trade liberalization. Finally, the last three rows in table 7 report $p$-values from three specification tests suggested by Arellano and Bond (1991). The tests indicate that the original error term $v_{i t}$, is serially uncorrelated, that the moment conditions are well specified, and OID tests fail to reject the validity of our instruments. ${ }^{29}$

We also extended the panel results on trade liberalization to the Heckscher-Ohlin setting by interacting the liberalization dummy with capital-labor ratio (please see online appendix at http://faculty.insead.edu/dutt/unemp). Across specifications (pooled OLS, fixed-effects, Arellano-Bond GMM) neither the liberalization dummy variable nor their interaction with capital-labor ratio are significant. In this sense, our panel results simply

\footnotetext{
${ }^{28}$ This correlation goes to zero only as $T$ gets large. For our data $T=7$ for the majority of countries, so this correlation does not vanish.

${ }^{29} \mathrm{We}$ also used the unweighted tariff rate for which we have the most comprehensive data over time. Similar to the results with the liberalization dummy, we find that countries who initiated a decline in their overall unweighted tariffs experienced a fall in their unemployment rates after a lag of three years. There is no evidence for a contemporaneous rise in the unemployment rate. These results are available in the online appendix.
} 
replicate our cross-sectional findings for the Heckscher-Ohlin specification.

\section{Conclusions}

In this paper, we present a model of trade and unemployment, in which unemployment is search induced and trade arises as a result of Heckscher-Ohlin (H-O) comparative advantage based on differences in factor proportions and/or Ricardian comparative advantage based on relative technological differences. We also discuss comparative advantage arising out of intersectoral and international differences in search frictions, efficiency and intensity. Our cross-sectional results provide fairly strong evidence for the steady-state prediction arising when trade is primarily driven by Ricardian comparative advantage: protection increases unemployment rates both across countries. This relationship is robust to controlling for employment laws, trade union power, civil liberties, country and labor force size. Resolving endogeneity concerns through the use of instrumental variables estimation leaves our results qualitatively unaffected. When we consider permanent trade liberalization episodes, we observe an immediate rise in unemployment; in the longer-term our estimates imply a reversal of this rise and an eventual decline in unemployment in the steady-state. Overall, we find a striking difference in the short versus long-run responsiveness of unemployment to trade liberalization. Finally, there is only weak and non-robust evidence for the Heckscher-Ohlin proposition which states that the impact of trade policies on unemployment is conditional on whether the country is labor abundant or capital abundant. We interpret this as the offsetting of the Heckscher-Ohlin type composition effects by Ricardian-type productivity-related effects, rather than the complete absence of the former. 


\section{References}

[1] Alesina, A., Perotti, R., 1996. Income distribution, political instability, and investment. European Economic Review 40, 1203-1228.

[2] Anderson, J., Marcouiller, D., 2002. Trade, insecurity and home bias. Review of Economics and Statistics $84,345-52$.

[3] Anderson, J., Neary, P.,1994. Measuring the restrictiveness of trade policy. World Bank Economic Review 8, 151-169.

[4] Arellano, M., Bond, S.,1991. Some tests of specification for panel data: Monte Carlo evidence and an application to employment equations. Review of Economic Studies 58, 277-297.

[5] Botero, J., Djankov, S., Porta, R., Lopez-De-Silanes, F., Shleifer, A., 2004. The regulation of labor. Quarterly Journal of Economics 119(4), 1339-1382.

[6] Davidson, C., Martin, L., Matusz, S.,1999. Trade and search-generated unemployment. Journal of International Economics 48, 271-299.

[7] Davidson, C. and Matusz, S., 2004. International Trade and Labor larkets: Theory, Evidence, and Policy Implications, W. E. Upjohn Institute, Kalamazoo, MI.

[8] Davidson, C., Matusz, S., 2005. Trade and turnover: theory and evidence. Review of International Economics 13, 861-880.

[9] Easterly, W., Levine, R., 2001. It's not factor accumulation: stylized facts and growth models. World Bank Economic Review 15, 177-219.

[10] Felbermayr, G., Prat, J., Schmerer, H., 2008. Globalization and labor market outcomes: wage bargaining, search frictions, and firm heterogeneity. IZA Discussion Papers 3363, Institute for the Study of Labor (IZA).

[11] Frankel, J., Romer, D., 1999. Does trade cause growth?. American Economic Review 89, 379-399.

[12] Helpman, E., Itskhoki, O., 2007. Labor market rigidities, trade and unemployment. NBER working paper No. 13365.

[13] Janiak, A., 2007. Does trade liberalization lead to job loss? Theory and some evidence. Mimeo, Universidad de Chile.

[14] Kee, H. L., Nicita, A., Olarreaga, M., 2006. Estimating trade restrictiveness indices. Policy Research Working Paper Series 3860, The World Bank, Washington DC. 
[15] Lee, D., Wolpin, K., 2006. Intersectoral labor mobility and the growth of the service sector. Econometrica $74,1-46$.

[16] Limao, N., Panagariya, A., 2007. Inequality and endogenous trade policy outcomes. Journal of International Economics 72, 292-309.

[17] Magee, C., Davidson, C., Matusz, S., 2005. "Trade, turnover and tithing," Journal of International Economics 66, 157-76.

[18] Mitra, D., Ranjan, P., 2007. Offshoring and unemployment. NBER Working Paper No. 13149.

[19] Moore, M., Ranjan, P., 2005. Globalization vs. skill biased technical change: implications for unemployment and wage inequality. Economic Journal 115, 391-422.

[20] Pissarides, C., 2000. Equilibrium Unemployment Theory, 2nd edition, MIT Press, Cambridge, MA.

[21] Rama, M., Artecona, R., 2002. A Database of Labor Market Indicators Across Countries. Development Research Group, The World Bank, Washington, DC.

[22] Ramey, G., Ramey, V., 1995. Cross-country evidence on the link between volatility and growth. American Economic Review 85, 1138-1151.

[23] Rodriguez F., Rodrik, D., 2000. Trade policy and economic growth: a skeptic's guide to the crossnational evidence, in B. Bernanke and K. Rogoff eds. NBER Macroeconomics Annual, MIT Press.

[24] Rodrik, D.,1995. Political economy of trade policy, in Grossman, G. and Rogoff, K. (Eds.) Handbook of International Economics vol. III, Elsevier Science, Amsterdam.

[25] Rodrik, D., Subramanian, A., Trebbi, F., 2004. Institutions rule: the primacy of institutions over geography and integration in economic development. Journal of Economic Growth 9, 131-165.

[26] Rose, Andrew K., 2004. Do we really know that the WTO increases trade?. American Economic Review 94, 98-114.

[27] Stock, J., Wright J., Yogo, M., 2002. A survey of weak Instruments and weak Identification in generalized method of moments. Journal of Business \& Economic Statistics 20, 518-529.

[28] Wacziarg, R., Wallack, J., 2004. Trade liberalization and intersectoral labor movements. Journal of International Economics 64(2), 411-39.

[29] Wacziarg, R., Welch, K., 2008. Trade liberalization and growth: new evidence. World Bank Economic Review 22, 187-231. 
Table 1: Summary Statistics

\begin{tabular}{lllll}
\hline Variable & \multicolumn{2}{l}{ Cross-Section Data } & \multicolumn{2}{l}{ Panel Data } \\
& $\boldsymbol{N}$ & Mean & $\boldsymbol{N}$ & Mean \\
\hline Unemployment Rate & 90 & 9.87 & 1586 & 8.95 \\
Unweighted Tariff & 175 & 15.13 & 1290 & 13.37 \\
Overall Trade Restrictiveness Index & 89 & 16.13 & & \\
GCR Trade Barriers & 115 & 3.19 & & \\
Import Duty & 131 & 8.78 & & \\
Openness: (X+M)/GDP & 182 & 84.21 & & \\
GDP & 184 & 16.84 & 2065 & 18.09 \\
Population (ages 15-64) & 204 & 19.99 & 2484 & 15.48 \\
Civil Liberties & 186 & 3.67 & 2150 & 2.97 \\
Employment laws index & 83 & 0.43 & & \\
Labor Union Power & 83 & 0.49 & & \\
Output Volatility & 182 & 6.17 & & \\
Black Market Premium & 121 & 4.99 & & \\
Capital-labor ratio & 115 & 9.24 & & \\
No. of years outside GATT/WTO & 185 & 21.69 & & \\
Domestic tax revenue share in total tax revenues & 93 & 0.8 & & \\
Labor market participation rate & 199 & 69.22 & 2484 & 68.01 \\
Female labor market participation rate & 199 & 55.6 & 2484 & 54.18 \\
Liberalization dummy & & & 1998 & 0.73 \\
\hline
\end{tabular}


Figure 1: Tariffs and Unemployment Rate (1990s)

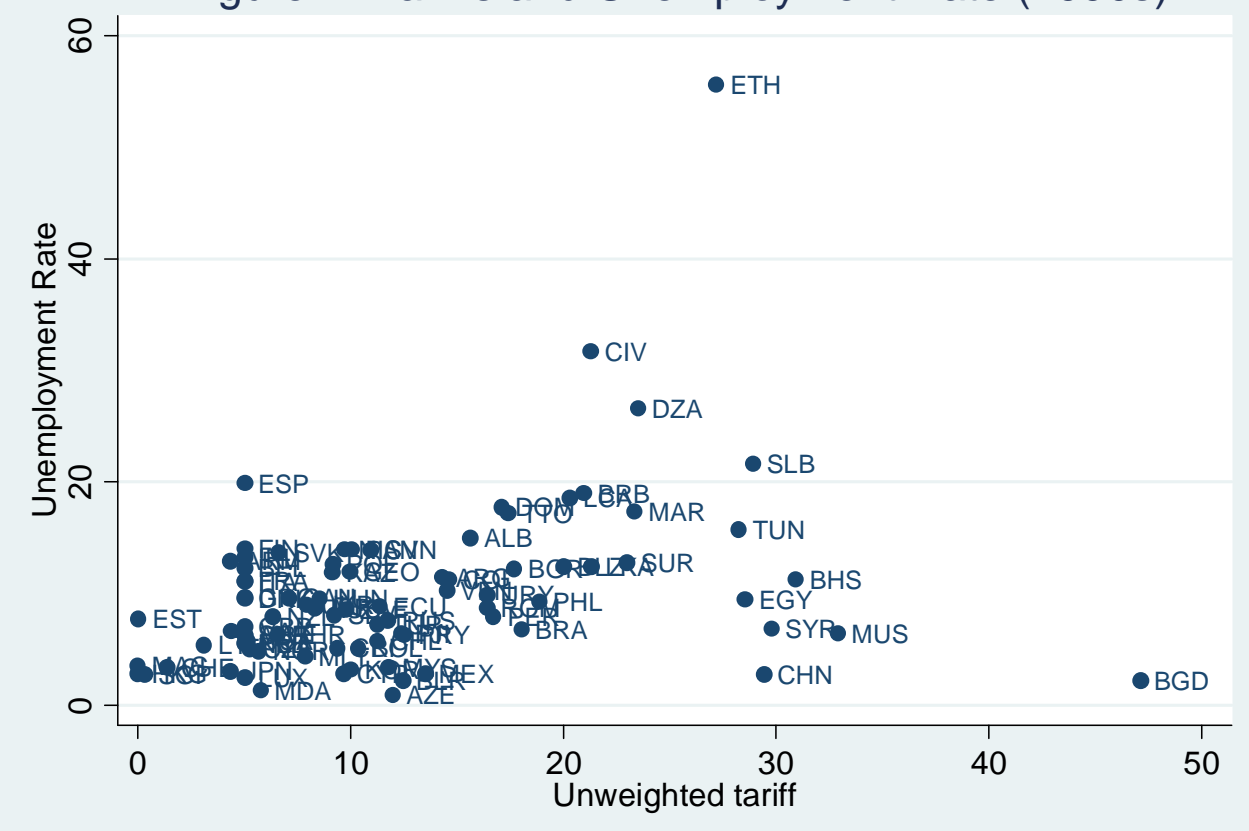


Table 2: The Effect of Trade Policies on the Unemployment Rate (Ricardian specification)

\begin{tabular}{|c|c|c|c|c|c|}
\hline & $(1)$ & (2) & (3) & (4) & (5) \\
\hline Unweighted Tariff & $\begin{array}{l}0.287^{*} \\
(0.148)\end{array}$ & & & & \\
\hline Overall Trade Restrictiveness Index & & $\begin{array}{c}0.308 * * * \\
(0.102)\end{array}$ & & & \\
\hline GCR trade barriers & & & $\begin{array}{c}1.124 * * \\
(0.501)\end{array}$ & & \\
\hline Import Duty & & & & $\begin{array}{c}0.597 * * * \\
(0.218)\end{array}$ & \\
\hline Openness: $(X+M) / G D P$ & & & & & $\begin{array}{c}-0.027 * * \\
(0.014)\end{array}$ \\
\hline Observations & 87 & 53 & 77 & 82 & 89 \\
\hline$R$-squared & 0.12 & 0.13 & 0.15 & 0.24 & 0.04 \\
\hline
\end{tabular}

All regressions include a constant (not reported). Robust standard errors in parentheses; * significant at 10\%; ${ }^{*}$ significa
All variables are averaged over the 1990s, except OTRI and GCR trade barriers which are available for a single year. 
Table 3: The Effect of Trade Policies on the Unemployment Rate (Ricardian specification; with controls)

\begin{tabular}{|c|c|c|c|c|c|}
\hline & (1) & (2) & (3) & (4) & (5) \\
\hline Unweighted Tariff & $\begin{array}{l}0.351^{* * *} \\
(0.098)\end{array}$ & & & & \\
\hline Overall Trade Restrictiveness Index & & $\begin{array}{l}0.179 * \\
(0.094)\end{array}$ & & & \\
\hline GCR trade barriers & & & $\begin{array}{l}1.402 * * \\
(0.587)\end{array}$ & & \\
\hline Import Duty & & & & $\begin{array}{l}0.492 * * * \\
(0.111)\end{array}$ & \\
\hline Openness: $(X+M) / G D P$ & & & & & $\begin{array}{l}-0.024^{*} \\
(0.013)\end{array}$ \\
\hline Employment laws index & $\begin{array}{l}-1.174 \\
(2.702)\end{array}$ & $\begin{array}{l}0.352 \\
(2.752)\end{array}$ & $\begin{array}{l}-2.035 \\
(2.697)\end{array}$ & $\begin{array}{l}-2.959 \\
(2.599)\end{array}$ & $\begin{array}{l}-2.788 \\
(2.960)\end{array}$ \\
\hline Labor Union Power & $\begin{array}{l}5.432 * \\
(2.856)\end{array}$ & $\begin{array}{l}0.742 \\
(3.797)\end{array}$ & $\begin{array}{l}4.961 \\
(2.977)\end{array}$ & $\begin{array}{l}7.602^{* * * *} \\
(2.785)\end{array}$ & $\begin{array}{l}5.924^{*} \\
(3.116)\end{array}$ \\
\hline$G D P$ & $\begin{array}{l}0.010 \\
(1.120)\end{array}$ & $\begin{array}{l}-1.603 \\
(1.880)\end{array}$ & $\begin{array}{l}-0.481 \\
(1.190)\end{array}$ & $\begin{array}{l}0.062 \\
(1.157)\end{array}$ & $\begin{array}{l}-0.772 \\
(1.365)\end{array}$ \\
\hline Population (ages 15-64) & $\begin{array}{l}-0.732 \\
(1.219)\end{array}$ & $\begin{array}{l}1.037 \\
(2.181)\end{array}$ & $\begin{array}{l}-0.407 \\
(1.301)\end{array}$ & $\begin{array}{l}-0.459 \\
(1.203)\end{array}$ & $\begin{array}{l}-0.275 \\
(1.492)\end{array}$ \\
\hline Civil Liberties & $\begin{array}{l}-1.052 * * \\
(0.405)\end{array}$ & $\begin{array}{l}-0.745 \\
(1.065)\end{array}$ & $\begin{array}{l}-0.754 \\
(0.451)\end{array}$ & $\begin{array}{l}-0.726 \\
(0.466)\end{array}$ & $\begin{array}{l}0.186 \\
(0.672)\end{array}$ \\
\hline Output Volatility & $\begin{array}{l}0.335 \\
(0.302)\end{array}$ & $\begin{array}{l}0.336 \\
(0.354)\end{array}$ & $\begin{array}{l}0.007 \\
(0.319)\end{array}$ & $\begin{array}{l}0.302 \\
(0.281)\end{array}$ & $\begin{array}{l}0.271 \\
(0.335)\end{array}$ \\
\hline Black Market Premium & $\begin{array}{l}-0.015 \\
(0.028)\end{array}$ & $\begin{array}{l}0.013 \\
(0.035)\end{array}$ & $\begin{array}{l}-0.002 \\
(0.025)\end{array}$ & $\begin{array}{l}-0.028 \\
(0.029)\end{array}$ & $\begin{array}{l}-0.019 \\
(0.033)\end{array}$ \\
\hline Observations & 55 & 35 & 55 & 54 & 55 \\
\hline$R$-squared & 0.28 & 0.33 & 0.28 & 0.33 & 0.20 \\
\hline
\end{tabular}

\footnotetext{
All regressions include a constant (not reported).

Robust standard errors in parentheses; * significant at 10\%; ** significant at 5\%; *** significant at $1 \%$

All variables are averaged over the 1990s, except OTRI and GCR trade barriers which are available for a single year.

Employment laws index and labor union power are available only for 1997.
} 
Table 4: Instrumental Variables Results for the Effect of Trade Policies on Unemployment Rate (Ricardian specification; with controls)

\begin{tabular}{|c|c|c|c|c|c|}
\hline & (1) & (2) & (3) & (4) & (5) \\
\hline Unweighted Tariff & $\begin{array}{l}0.750 * * \\
(0.345)\end{array}$ & & & & \\
\hline Overall Trade Restrictiveness Index & & $\begin{array}{l}0.101 \\
(0.190)\end{array}$ & & & \\
\hline GCR trade barriers & & & $\begin{array}{l}1.994^{* * *} \\
(0.560)\end{array}$ & & \\
\hline Import Duty & & & & $\begin{array}{l}0.664^{* * *} \\
(0.196)\end{array}$ & \\
\hline Openness: $(X+M) / G D P$ & & & & & $\begin{array}{l}-0.065 * * \\
(0.028)\end{array}$ \\
\hline Employment laws index & $\begin{array}{l}-2.331 \\
(2.923)\end{array}$ & $\begin{array}{l}-2.153 \\
(3.276)\end{array}$ & $\begin{array}{l}-4.438 * \\
(2.422)\end{array}$ & $\begin{array}{l}-4.656 * \\
(2.402)\end{array}$ & $\begin{array}{l}-4.599 \\
(2.905)\end{array}$ \\
\hline Labor Union Power & $\begin{array}{l}5.839 \\
(4.257)\end{array}$ & $\begin{array}{l}2.936 \\
(5.386)\end{array}$ & $\begin{array}{l}8.357 * * \\
(3.450)\end{array}$ & $\begin{array}{l}8.847 * * \\
(3.597)\end{array}$ & $\begin{array}{l}6.895 * * \\
(2.995)\end{array}$ \\
\hline$G D P$ & $\begin{array}{l}1.682 \\
(2.319)\end{array}$ & $\begin{array}{l}-2.638 \\
(2.470)\end{array}$ & $\begin{array}{l}-0.437 \\
(1.235)\end{array}$ & $\begin{array}{l}0.095 \\
(1.647)\end{array}$ & $\begin{array}{l}1.255 \\
(2.110)\end{array}$ \\
\hline Population (ages 15-64) & $\begin{array}{l}-2.165 \\
(2.619)\end{array}$ & $\begin{array}{l}2.467 \\
(2.781)\end{array}$ & $\begin{array}{l}-0.043 \\
(1.389)\end{array}$ & $\begin{array}{l}-0.501 \\
(1.842)\end{array}$ & $\begin{array}{l}-3.192 \\
(2.658)\end{array}$ \\
\hline Civil Liberties & $\begin{array}{l}-1.645^{* *} \\
(0.760)\end{array}$ & $\begin{array}{l}-0.706 \\
(1.631)\end{array}$ & $\begin{array}{l}-0.935^{* *} \\
(0.369)\end{array}$ & $\begin{array}{l}-1.027 * * \\
(0.438)\end{array}$ & $\begin{array}{l}1.417 \\
(1.067)\end{array}$ \\
\hline Output Volatility & $\begin{array}{l}0.284 \\
(0.367)\end{array}$ & $\begin{array}{l}0.607 \\
(0.506)\end{array}$ & $\begin{array}{l}0.333 \\
(0.376)\end{array}$ & $\begin{array}{l}0.151 \\
(0.348)\end{array}$ & $\begin{array}{l}0.405 \\
(0.294)\end{array}$ \\
\hline Black Market Premium & $\begin{array}{l}-0.036 \\
(0.040)\end{array}$ & $\begin{array}{l}0.004 \\
(0.056)\end{array}$ & $\begin{array}{l}-0.036 \\
(0.036)\end{array}$ & $\begin{array}{l}-0.039 \\
(0.033)\end{array}$ & $\begin{array}{l}-0.055 \\
(0.037)\end{array}$ \\
\hline Observations & 44 & 25 & 44 & 43 & 55 \\
\hline First stage partial R-squared & 0.18 & 0.37 & 0.52 & 0.38 & 0.3 \\
\hline OID test $p$-value & 0.84 & 0.01 & 0.9 & 0.76 & 0.13 \\
\hline
\end{tabular}

All regressions include a constant (not reported).

Robust standard errors in parentheses; * significant at $10 \%$;** significant at $5 \%$; *** significant at $1 \%$

Instruments for trade policies: Share of tax revenues from domestic sources; Number of years the country stayed outside GATT since inception in 1948

Instruments for $(X+M / G D P)$ : Frankel-Romer instruments and remoteness index from Rose (2004).

The last two rows report a partial $R^{2}$ from the first stage regressions and the $p$-value from a test of overidentification. 
Table 5: The Effect of Trade Policies on the Unemployment Rate (Ricardian specification; Controlling for Labor Market Participation)

\begin{tabular}{|c|c|c|c|c|c|c|}
\hline & $(1)$ & $(2)$ & $(3)$ & (4) & (5) & (6) \\
\hline Unweighted Tariff & $\begin{array}{l}0.267 * * * \\
(0.089)\end{array}$ & $\begin{array}{l}0.686 * \\
(0.403)\end{array}$ & $\begin{array}{l}0.659 * \\
(0.360)\end{array}$ & & & \\
\hline Import duty & & & & $\begin{array}{l}0.336 * * \\
(0.154)\end{array}$ & $\begin{array}{l}0.500 * * \\
(0.201)\end{array}$ & $\begin{array}{l}0.453 * * \\
(0.204)\end{array}$ \\
\hline Employment laws index & $\begin{array}{l}-3.440 \\
(2.577)\end{array}$ & $\begin{array}{l}-3.345 \\
(2.774)\end{array}$ & $\begin{array}{l}-3.428 \\
(2.878)\end{array}$ & $\begin{array}{l}-4.999 * \\
(2.588)\end{array}$ & $\begin{array}{l}-5.809 * * \\
(2.413)\end{array}$ & $\begin{array}{l}-5.638 * * \\
(2.518)\end{array}$ \\
\hline Labor Union Power & $\begin{array}{l}6.125 * * \\
(2.906)\end{array}$ & $\begin{array}{l}5.250 \\
(3.888)\end{array}$ & $\begin{array}{l}5.316 \\
(3.775)\end{array}$ & $\begin{array}{l}7.446 * * * \\
(2.709)\end{array}$ & $\begin{array}{l}7.114 * * \\
(2.986)\end{array}$ & $\begin{array}{l}7.073 * * \\
(2.935)\end{array}$ \\
\hline$G D P$ & $\begin{array}{l}-0.428 \\
(1.019)\end{array}$ & $\begin{array}{l}1.487 \\
(2.423)\end{array}$ & $\begin{array}{l}1.330 \\
(2.227)\end{array}$ & $\begin{array}{l}-0.718 \\
(1.028)\end{array}$ & $\begin{array}{l}-0.388 \\
(1.356)\end{array}$ & $\begin{array}{l}-0.592 \\
(1.354)\end{array}$ \\
\hline Population (ages 15-64) & $\begin{array}{l}0.092 \\
(1.115)\end{array}$ & $\begin{array}{l}-1.937 \\
(2.681)\end{array}$ & $\begin{array}{l}-1.770 \\
(2.495)\end{array}$ & $\begin{array}{l}0.645 \\
(1.119)\end{array}$ & $\begin{array}{l}-0.013 \\
(1.452)\end{array}$ & $\begin{array}{l}0.189 \\
(1.471)\end{array}$ \\
\hline Civil Liberties & $\begin{array}{l}-1.581^{* * *} \\
(0.520)\end{array}$ & $\begin{array}{l}-1.965^{* *} \\
(0.878)\end{array}$ & $\begin{array}{l}-1.946 * * \\
(0.891)\end{array}$ & $\begin{array}{l}-1.398^{* *} \\
(0.537)\end{array}$ & $\begin{array}{l}-2.037 * * * \\
(0.548)\end{array}$ & $\begin{array}{l}-2.077 * * * \\
(0.570)\end{array}$ \\
\hline Output Volatility & $\begin{array}{l}0.342 \\
(0.309)\end{array}$ & $\begin{array}{l}0.229 \\
(0.380)\end{array}$ & $\begin{array}{l}0.230 \\
(0.399)\end{array}$ & $\begin{array}{l}0.286 \\
(0.296)\end{array}$ & $\begin{array}{l}0.126 \\
(0.349)\end{array}$ & $\begin{array}{l}0.148 \\
(0.381)\end{array}$ \\
\hline Black Market Premium & $\begin{array}{l}0.010 \\
(0.038)\end{array}$ & $\begin{array}{l}-0.009 \\
(0.041)\end{array}$ & $\begin{array}{l}-0.007 \\
(0.045)\end{array}$ & $\begin{array}{l}0.007 \\
(0.039)\end{array}$ & $\begin{array}{l}0.006 \\
(0.036)\end{array}$ & $\begin{array}{l}0.005 \\
(0.041)\end{array}$ \\
\hline Labor market participation rate & $\begin{array}{l}-0.263 \\
(0.164)\end{array}$ & $\begin{array}{l}-0.295 \\
(0.189)\end{array}$ & $\begin{array}{l}-0.300 \\
(0.394)\end{array}$ & $\begin{array}{l}-0.323^{*} \\
(0.179)\end{array}$ & $\begin{array}{l}-0.347^{* *} \\
(0.174)\end{array}$ & $\begin{array}{l}-0.287 \\
(0.337)\end{array}$ \\
\hline Female labor market participation rate & $\begin{array}{l}0.010 \\
(0.120)\end{array}$ & $\begin{array}{l}0.083 \\
(0.157)\end{array}$ & $\begin{array}{l}0.082 \\
(0.252)\end{array}$ & $\begin{array}{l}0.041 \\
(0.138)\end{array}$ & $\begin{array}{l}0.016 \\
(0.136)\end{array}$ & $\begin{array}{l}-0.022 \\
(0.222)\end{array}$ \\
\hline $\begin{array}{l}\text { Observations } \\
R \text {-sauared }\end{array}$ & 55 & 44 & 44 & 54 & 43 & 43 \\
\hline $\begin{array}{l}\text { First stage partial R-squared } \\
\text { (trade policy) }\end{array}$ & & 0.15 & 0.17 & & 0.35 & 0.38 \\
\hline $\begin{array}{l}\text { First stage partial R-squared } \\
\text { (participation rate)) }\end{array}$ & & & 0.32 & & & 0.32 \\
\hline OID test $p$-value & & 0.96 & 0.37 & & 0.66 & 0.38 \\
\hline
\end{tabular}

All variables are averaged over the 1990s. Employment laws index and labor union power are available only for 1997.

All regressions include a constant (not reported). Robust standard errors in parentheses; * significant at 10\%; ** significant at 5\%; *** significant at $1 \%$ Instruments for trade policies: Share of tax revenues from domestic sources; Number of years the country stayed outside GATT since inception in 1948 .

Additional instruments when labor market participation is instrumented: Percentage of working age population; Crude death rate per 1000.

Columns 1 and 4 present OLS estimates; columns 2, 3, 5 and 6 present IV estimates. In columns 2 and 5 we only instrument trade policies. In columns 3 and 6 we also instrument labor market participation.

The last two rows report a partial $R^{2}$ from the first stage regressions and the $p$-value from a test of overidentification. 
Table 6: The Effect of Trade Policies on the Unemployment Rate (Hecksher-Ohlin specification; with controls)

\begin{tabular}{|c|c|c|c|c|c|}
\hline & $\begin{array}{l}\text { Unweighted } \\
\text { tariff }\end{array}$ & $\begin{array}{l}\text { Overall Trade } \\
\text { Restrictiveness } \\
\text { Index }\end{array}$ & $\begin{array}{l}\text { GCR Trade } \\
\text { Barriers }\end{array}$ & Import Duty & $\begin{array}{l}\text { Openness } \\
(X+M / G D P)\end{array}$ \\
\hline Trade Policy Measure & $\begin{array}{l}0.227 \\
(0.244)\end{array}$ & $\begin{array}{l}0.958 \\
(0.856)\end{array}$ & $\begin{array}{l}9.230 * \\
(4.888)\end{array}$ & $\begin{array}{l}3.824 * * \\
(1.443)\end{array}$ & $\begin{array}{l}0.158 \\
(0.188)\end{array}$ \\
\hline Trade Policy*Capital-labor ratio & $\begin{array}{l}0.015 \\
(0.025)\end{array}$ & $\begin{array}{l}-0.089 \\
(0.094)\end{array}$ & $\begin{array}{l}-0.763 \\
(0.503)\end{array}$ & $\begin{array}{l}-0.349 * * \\
(0.149)\end{array}$ & $\begin{array}{l}-0.017 \\
(0.018)\end{array}$ \\
\hline Capital-labor ratio & $\begin{array}{l}1.427 \\
(1.911)\end{array}$ & $\begin{array}{l}1.268 \\
(3.281)\end{array}$ & $\begin{array}{l}4.330 * \\
(2.538)\end{array}$ & $\begin{array}{l}4.521^{* *} \\
(2.220)\end{array}$ & $\begin{array}{l}1.350 \\
(2.364)\end{array}$ \\
\hline Employment laws index & $\begin{array}{l}-2.029 \\
(2.667)\end{array}$ & $\begin{array}{l}-1.126 \\
(3.032)\end{array}$ & $\begin{array}{l}-2.477 \\
(2.725)\end{array}$ & $\begin{array}{l}-3.208 \\
(2.596)\end{array}$ & $\begin{array}{l}-3.750 \\
(2.940)\end{array}$ \\
\hline Labor Union Power & $\begin{array}{l}6.346^{*} \\
(3.641)\end{array}$ & $\begin{array}{l}2.521 \\
(6.177)\end{array}$ & $\begin{array}{l}5.270 \\
(3.204)\end{array}$ & $\begin{array}{l}6.316^{*} \\
(3.375)\end{array}$ & $\begin{array}{l}7.768 * * \\
(3.522)\end{array}$ \\
\hline$G D P$ & $\begin{array}{l}-2.399 \\
(2.273)\end{array}$ & $\begin{array}{l}-2.639 \\
(3.658)\end{array}$ & $\begin{array}{l}-3.622 * \\
(2.103)\end{array}$ & $\begin{array}{l}-4.478^{*} \\
(2.210)\end{array}$ & $\begin{array}{l}-1.298 \\
(2.210)\end{array}$ \\
\hline Population (ages 15-64) & $\begin{array}{l}1.764 \\
(2.456)\end{array}$ & $\begin{array}{l}2.111 \\
(3.914)\end{array}$ & $\begin{array}{l}2.779 \\
(2.248)\end{array}$ & $\begin{array}{l}4.107^{*} \\
(2.328)\end{array}$ & $\begin{array}{l}0.181 \\
(2.317)\end{array}$ \\
\hline Civil Liberties & $\begin{array}{l}-0.903^{*} \\
(0.532)\end{array}$ & $\begin{array}{l}-0.904 \\
(1.002)\end{array}$ & $\begin{array}{l}-0.940 * \\
(0.548)\end{array}$ & $\begin{array}{l}-0.874 \\
(0.596)\end{array}$ & $\begin{array}{l}0.224 \\
(0.856)\end{array}$ \\
\hline Output Volatility & $\begin{array}{l}0.179 \\
(0.419)\end{array}$ & $\begin{array}{l}0.632 \\
(0.532)\end{array}$ & $\begin{array}{l}0.325 \\
(0.416)\end{array}$ & $\begin{array}{l}0.329 \\
(0.347)\end{array}$ & $\begin{array}{l}0.472 \\
(0.504)\end{array}$ \\
\hline Black market premium & $\begin{array}{l}-0.064 \\
(0.061)\end{array}$ & $\begin{array}{l}0.027 \\
(0.070)\end{array}$ & $\begin{array}{l}-0.035 \\
(0.039)\end{array}$ & $\begin{array}{l}-0.025 \\
(0.042)\end{array}$ & $\begin{array}{l}-0.037 \\
(0.049)\end{array}$ \\
\hline Observations & 48 & 29 & 48 & 47 & 48 \\
\hline$R$-squared & 0.31 & 0.42 & 0.37 & 0.42 & 0.27 \\
\hline Positive relation & 48 & 22 & 48 & 31 & 7 \\
\hline Negative relation & 0 & 7 & 0 & 16 & 41 \\
\hline
\end{tabular}

Robust standard errors in parentheses; * significant at $10 \%$; ** significant at $5 \%$; *** significant at $1 \%$

All variables are averaged over the 1990s, except OTRI and GCR which are available for a single year.

Employment laws index and labor union power are available only for 1997.

The last 2 rows divides the number of observations into countries that have a positive and countries that have a negative relation between trade policy and unemployment rate. 
Table 7: The Effect of Permanent Trade Liberalization on Unemployment Rate (Ricardian Specification)

\begin{tabular}{|c|c|c|c|c|c|}
\hline & $(1)$ & $(2)$ & (3) & (4) & (5) \\
\hline Unemployment $(t-1)$ & $\begin{array}{l}0.963 * * * \\
(0.009)\end{array}$ & $\begin{array}{l}0.773 * * * \\
(0.053)\end{array}$ & $\begin{array}{l}0.635^{* * * *} \\
(0.010)\end{array}$ & $\begin{array}{l}0.616 * * * \\
(0.007)\end{array}$ & $\begin{array}{l}0.597 * * * \\
(0.010)\end{array}$ \\
\hline Liberalization dummy $(t)$ & $\begin{array}{l}0.814^{* *} \\
(0.386)\end{array}$ & $\begin{array}{l}0.701^{*} \\
(0.385)\end{array}$ & $\begin{array}{l}0.877 * * * \\
(0.157)\end{array}$ & $\begin{array}{l}0.925 * * * \\
(0.146)\end{array}$ & $\begin{array}{l}0.818 * * * \\
(0.208)\end{array}$ \\
\hline Liberalization dummy $(t-1)$ & $\begin{array}{l}-0.841^{*} \\
(0.429)\end{array}$ & $\begin{array}{l}-0.664^{*} \\
(0.363)\end{array}$ & $\begin{array}{l}-1.983 * * * \\
(0.179)\end{array}$ & $\begin{array}{l}-1.549 * * * \\
(0.283)\end{array}$ & $\begin{array}{l}-1.346^{* * * *} \\
(0.211)\end{array}$ \\
\hline Liberalization dummy $(t-2)$ & $\begin{array}{l}-0.756^{*} \\
(0.429)\end{array}$ & $\begin{array}{l}-0.653^{*} \\
(0.375)\end{array}$ & $\begin{array}{l}-0.412^{* *} \\
(0.194)\end{array}$ & $\begin{array}{l}-0.481 * \\
(0.254)\end{array}$ & $\begin{array}{l}-0.838 * * \\
(0.335)\end{array}$ \\
\hline Liberalization dummy $(t-3)$ & $\begin{array}{l}0.418 \\
(0.325)\end{array}$ & $\begin{array}{l}0.233 \\
(0.297)\end{array}$ & $\begin{array}{l}0.015 \\
(0.177)\end{array}$ & $\begin{array}{l}0.036 \\
(0.188)\end{array}$ & $\begin{array}{l}0.265 \\
(0.218)\end{array}$ \\
\hline Liberalization dummy $(t-4)$ & $\begin{array}{l}-0.117 \\
(0.246)\end{array}$ & $\begin{array}{l}0.099 \\
(0.270)\end{array}$ & $\begin{array}{l}0.207 \\
(0.185)\end{array}$ & $\begin{array}{l}0.125 \\
(0.212)\end{array}$ & $\begin{array}{l}-0.206 \\
(0.212)\end{array}$ \\
\hline$G D P(t)$ & $\begin{array}{l}-0.196 \\
(0.127)\end{array}$ & $\begin{array}{l}-2.306 * * * \\
(0.709)\end{array}$ & $\begin{array}{l}-7.323 * * * \\
(0.366)\end{array}$ & $\begin{array}{l}-7.011 * * * \\
(0.332)\end{array}$ & $\begin{array}{l}-7.775^{* * * *} \\
(0.347)\end{array}$ \\
\hline Population (ages 15-64) (t) & $\begin{array}{l}0.217 \\
(0.138)\end{array}$ & $\begin{array}{l}5.808 * * * \\
(1.641)\end{array}$ & $\begin{array}{l}9.531 * * * \\
(1.988)\end{array}$ & $\begin{array}{l}9.718 * * * \\
(1.477)\end{array}$ & $\begin{array}{l}8.872 * * * \\
(2.027)\end{array}$ \\
\hline Civil liberties $(t)$ & $\begin{array}{l}-0.052 \\
(0.056)\end{array}$ & $\begin{array}{l}-0.132 \\
(0.151)\end{array}$ & $\begin{array}{l}-0.480 * * * \\
(0.031)\end{array}$ & $\begin{array}{l}-0.205 * * * \\
(0.038)\end{array}$ & $\begin{array}{l}-0.116^{* * * *} \\
(0.035)\end{array}$ \\
\hline Labor market participation rate $(t)$ & & & & & $\begin{array}{l}-0.191 \\
(0.120)\end{array}$ \\
\hline Female labor market participation rate $(t)$ & & & & & $\begin{array}{l}0.061 \\
(0.081)\end{array}$ \\
\hline Observations & 1096 & 1096 & 1011 & 1011 & 1011 \\
\hline $\begin{array}{l}\text { Number of countries } \\
\text { Specification test ( } p \text {-values) }\end{array}$ & 73 & 73 & 72 & 72 & 72 \\
\hline OID test & & & 1 & 1 & 1 \\
\hline Serial correlation: $A R(1)$ test & & & 0.09 & 0.09 & 0.08 \\
\hline Serial correlation: $A R(2)$ test & & & 0.14 & 0.14 & 0.13 \\
\hline
\end{tabular}

Robust standard errors in parentheses; * significant at $10 \%$;* significant at $5 \%$; *** significant at $1 \%$

Column 1 shows pooled OLS estimates; column 2 shows within-estimates with country-fixed effects; columns 3-5 present Arellano-Bond GMM (difference) estimates. In columns 3-5, all variables are in first-differences which removes country-fixed effects and the lagged differenced unemployment is instrumented by higher lags of the unemployment level. Column 3 treats the liberalization dummy as pre-determined and column 4 treats it as endogenous. Column 5 adds participation rates to column 4 . 